Biuletyn Historii Sztuki LXXXII:2020, nr 4

ISSN 00063967

WoJciech SowaŁa

Kraków, Instytut Historii Sztuki UJ

https://orcid.org/0000-0002-6366-263X

\title{
Średniowieczna architektura \\ kościoła św. Jana Chrzciciela w Skalbmierzu
}

\author{
Medieval Architecture of the Church \\ of St John the Baptist in Skalbmierz
}


Kolegiata św. Jana Chrzciciela w Skalbmierzu była jedną z najstarszych i najważniejszych kapituł w diecezji krakowskiej. W artykule przeanalizowano relikty XII-wiecznego kościoła i postawiono tezę o innym, niż dotychczas przyjmowane, kształcie wschodniej partii świątyni. Następnie, w oparciu o badania architektury i przekazów źródłowych postawiono tezę o wykonaniu przebudowy pomiędzy 1443 a $1460 \mathrm{r}$. Wskazano, że proporcje budowli i detal architektoniczny wykazują pokrewieństwo z analogicznymi elementami kościoła Bożego Ciała w Krakowie, a kompozycja górnych partii elewacji wewnętrznych świadczy o znajomości śląskiej tradycji budowlanej. Złożony przekaz ideowy architektury kolegiaty, w którym wykorzystano zarówno relikty starszej budowli, jak i najmodniejszy wówczas modus stylowy sugerują przemyślany plan odbudowy i zaangażowanie w nią ówczesnego skalbmierskiego prepozyta Jakuba z Sienna.

Słowa-klucze: architektura średniowieczna, architektura małopolska, Skalbmierz, Jakub z Sienna

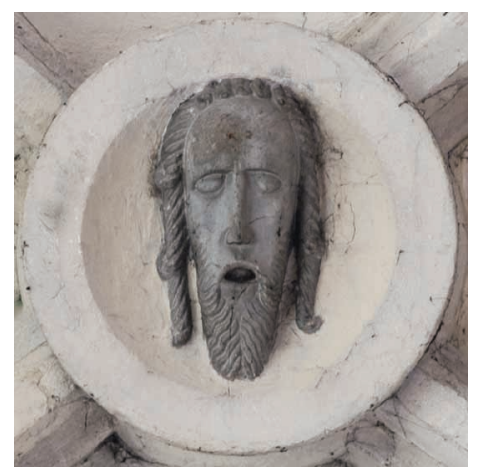

The Collegiate Church of St John the Baptist in Skalbmierz is one of the oldest and most important Chapters in the Cracow Diocese. In the paper, relics of the $12^{\text {th }}$-century church are analysed, and the thesis claiming that the shape of the eastern fragment of the church was different from the one assumed to-date has been put forth. Furthermore, resorting to the investigation of the architecture and source records, the thesis claiming that in 1443-1460 the church's remodelling was conducted has been formulated. The fact that the building's proportions and the architectural details show analogies with the respective elements of the Cracow Church of Corpus Christi has been pointed to; moreover, the composition of the upper parts of internal elevations testifying to the knowledge of the Silesian construction tradition has been emphasized. The complex ideological message of the architecture of the Collegiate Church in which both relics of the older building and the style mode most jin vogue at the time are combined suggest a carefully thought out plan for the remodelling of the Collegiate Church of St John the Baptist and the fact that the Skalbmierz Provost Jakub of Sienno was involved in the project.

Keywords: Medieval architecture, architecture of Lesser Poland, Skalbmierz, Jakub of Sienno 
$\mathrm{K}$

ościół pod wezwaniem św. Jana Chrzciciela w Skalbmierzu, choć na stałe wszedł do syntez architektury romańskiej i gotyckiej w Polsce, właściwie nigdy nie stał się przedmiotem szczegółowej analizy. W przypadku znakomicie zachowanych reliktów XII-wiecznej świątyni stało się tak zapewne w wyniku braku jakiegokolwiek detalu architektonicznego umożliwiającego precyzyjne datowanie czy analizę stylistyczną. Z kolei na nikłym zainteresowaniu XV-wieczną rozbudową zaważyła ogólna negatywna ocena architektury małopolskiej tego okresu. Dość przytoczyć ostatnie syntetyczne opracowania Tomasza Węcławowicza i Andrzeja Grzybkowskiego, którzy zgodnie stwierdzili, że po okresie rozkwitu za panowania Kazimierza Wielkiego architektura Małopolski przeżywała okres stagnacji ${ }^{1}$. Faktycznie, budowle z XV w. nie imponują ani rozmiarami, ani nowatorstwem rozwiązań inżynierskich czy artystycznych. Wręcz przeciwnie, wyraźnie zauważalny jest retrospektywny charakter ówczesnych fundacji, nawiązujący do wzorów wypracowanych w XIV w. Ambicje fundatorów zdaje się wyczerpywać odwołanie do architektury stolicy czy upamiętnienie miejsca związanego z chlubną przeszłością ${ }^{2}$. Niemniej ranga skalbmierskiej kolegiaty, a także niecodzienny kształt świątyni, w której połączono w harmonijną całość XII-wieczne mury i wieże z XV-wiecznym korpusem nawowym, oraz wysoka jakość kamieniarki skłaniają do bliższego przyjrzenia się tej budowli.

Początki skalbmierskiego kościoła sięgają 1. połowy XII w., podobnie jak powstanie grupy kanonickiej w tym miejscu ${ }^{3}$. Pomimo iż mury tej pierwszej budowli są doskonale do dzisiaj czytelne (il. 1), świątynia właściwie nigdy nie stała się obiektem gruntownych badań. Jej dawną metrykę dostrzegli już Michał Baliński i Tymoteusz Lipiński, pytając w kontekście kościelnych wież, czy ,nie są to zabytki warowni, przez Konrada ks. Maz. wzniesionej?"4. Trop ten podjął Franciszek Sobieszczański ${ }^{5}$, natomiast Kazimierz Stronczyński datował cały kościół na rok około $1300^{6}$. Stanisław Kotarbiński, opierając się na

\footnotetext{
${ }^{1}$ Tomasz Węclawowicz, „Małopolska i Ziemie Ruskie Korony”, w: Architektura gotycka w Polsce, t. 1, red. Teresa Mroczko, Marian Arszyński (Warszawa: Instytut Sztuki PAN, 1995), s. 73-81 (Dzieje sztuki polskiej, 2); Andrzej GrZYBKowski, Gotycka architektura murowana w Polsce (Warszawa: Wydawnictwo UW, 2014), s. 165-185.

2 Jako modelowy przykład wskazuje się tutaj fundację kardynała Zbigniewa Oleśnickiego w Piotrawinie. Zob. Piotr Gryglewski, De Sacra Antiquitate. Odwołania do przeszłości w polskiej architekturze sakralnej XVI wieku (Warszawa: Neriton, 2012), s. 100-111.

${ }^{3}$ Andrzej Tomaszewski, Romańskie kościoły z emporami zachodnimi na obszarze Polski, Czech i Węier (Wrocław: Ossolineum, 1974), s. 115; Józef SzYMAŃskI, Kanonikat świecki w Małopolsce od końca XI do połowy XIII wieku (Lublin: Agencja Wydawniczo-Handlowa AD, 1995), s. 29.

${ }^{4}$ Michał BALIŃSKI, Tymoteusz LiPIŃSKi, Starożytna Polska pod względem historycznym, jeograficznym i statystycznym opisana. Przez..., t. 2 (Warszawa: S. Orgelbrand, 1844), s. 160.

${ }^{5}$ Franciszek SoBIESZCZAŃSKI, Wiadomości historyczne o sztukach pięknych w dawnej Polsce zawierajace opis dziejów i zabytków budownictwa, rzeźby, snycerstwa, malarstwa i rytownictwa, z krótkq wzmiankq o życiu i dziełach znakomitszych artystów krajowych, lub w Polsce zamieszkatych, t. 1 (Warszawa: S. Orgelbrand, 1847), s. 71.

${ }^{6}$ Kazimierz STRONCZYŃSKI, „Miasto poduchowne Szkalbmierz”, w: Kazimierza Stronczyńskiego opisy i widoki zabytków
} 


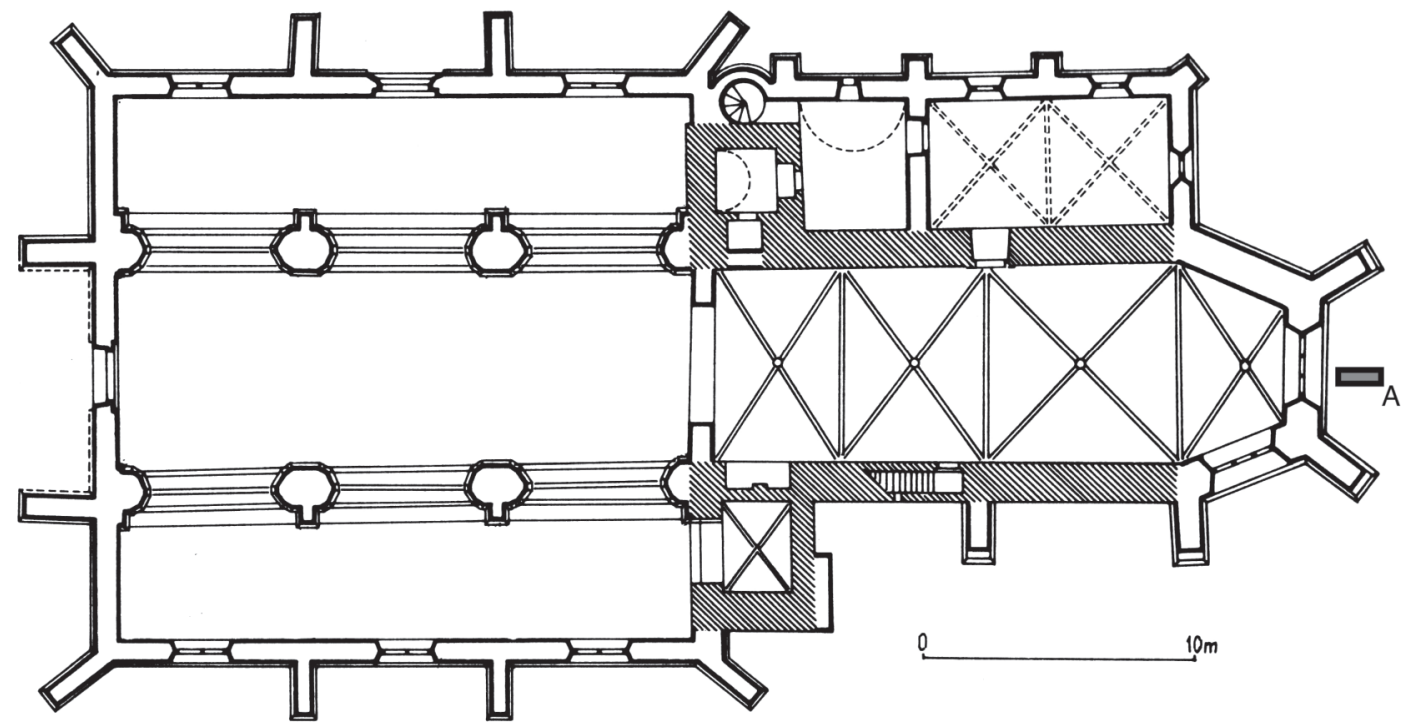

\section{Kościót św. Jana Chrzciciela w Skalbmierzu. Litera A zaznaczono położenie sarkofagu. Repr. za: Architektura gotycka w Polsce, t. 2, rys. 364}

aktach kapituły skalbmierskiej, stwierdził, że wieże wystawiono w XVIII w., co podtrzymali Władysław Łuszczkiewicz, Bronisław Chlebowski, Jan Wiśniewski i Bolesław Kumor $^{7}$. Dopiero Stanisław Tomkowicz przeprowadził dokładniejszą analizę, stwierdzając, że budynek składa się z przebudowanego w XV w. XIII-wiecznego kościoła, z którego zachowały się wieże i południowa ściana prezbiterium. Co ciekawe, badacz uważał, że romański korpus nawowy znajdował się w miejscu obecnego, a kościół miał plan analogiczny do świątyni w Kościelcu Proszowickim - z wieżami flankującymi prezbiterium ${ }^{8}$. $\mathrm{Na}$ tych ustaleniach (odrzucając istnienie korpusu nawowego) oparli się Tadeusz Szydłowski, Kazimiera Kutrzebianka, Zygmunt Świechowski i monografiści parafii ${ }^{9}$. Nieco więcej informacji przyniosły prowadzone w latach 1963-1964 sondażowe badania archeologiczne i architektoniczne, w wyniku których stwierdzono brak przewiązania pomiędzy

w Królestwie Polskim (1844-1855), t. 2: Gubernia Radomska, oprac. Karol GUTTMEJER (Warszawa: Krajowy Ośrodek Badań i Dokumentacji Zabytków, 2010), s. 66.

${ }^{7}$ Stanisław KotarbiŃski, „Historyczna wiadomość o kolegiacie szkalbmierskiej”, Pamiętnik Religijno-Moralny, nr 18 (1850), s. 410; Władysław Łuszczkiewicz, „Kościół pokolegijacki w Szkalbmierzu”, Przyjaciel Sztuki Kościelnej 2, nr 2 (1884), s. 30, Bronisław Chlebowski, „Skalbmierz”, w: Słownik geograficzny Królestwa Polskiego i innych krajów słowiańskich, red. Filip Sulimierski et al., t. 10 (Warszawa: Nakładem Filipa Sulimierskiego i Władysława Walewskiego, 1889), s. 638, Jan WiśNIEwsKI, Historyczny opis kościołów, miast, zabytków i pamiatek w pińczowskiem, skalbmierskiej i wiślickiem (Marjówka: Druk szkoły rzem. w Marjówce, 1927), s. 386, Bolesław Stanisław Kumor, Dzieje diecezji krakowskiej do roku 1795, t. 3 (Kraków: Wydawnictwo Świętego Stanisława BM, 2000), s. 185.

${ }^{8}$ Stanisław Tomkowicz, „Kollegiata świętego Jana Chrzciciela w Skalbmierzu. Reszty romańskiej budowy”, Sprawozdania Komisyi do Badania Historyi Sztuki w Polsce, t. 9, z. 1 (1913), kol. 107-112; rysunkowa rekonstrukcja planu kościoła zachowała się na odwrociu zdjęcia w Muzeum Narodowym w Krakowie (nr inw. MNK XX-f-3550).

${ }^{9}$ Tadeusz SzydŁowski, Pomniki Architektury epoki piastowskiej we województwach krakowskiem i kieleckiem (Kraków: Gebethner i Wolff, 1928), s. 35; „Skalbmierz”, w: Katalog Zabytków Sztuki w Polsce, t. 3: Województwo kieleckie, red. Jerzy Z. Łoziński, Barbara Wolff, z. 9: Powiat Pińczowski, oprac. Kazimiera KutrzebiankA, Jerzy Z. Łoziński, Barbara WolfF (Warszawa: Instytut Sztuki PAN, 1961), s. 83; Zygmunt Świechowski, Budownictwo romańskie w Polsce: katalog zabytków (Wrocław: Ossolineum, 1963), s. 243 i n.; Stanisław K. Olczak, Daniel Olszewski, Parafia Skalbmierz. Zarys dziejów (Kielce: Jedność, 2000), s. 69. 
2. Kościót św. Jana Chrzciciela w Skalbmierzu w XII wieku, przekrój perspektywiczny.

Repr. za: Andrzej Tomaszewski,

Romańskie kościoły z emporami zachodnimi na obszarze Polski, Czech

i Węgier, s. 118

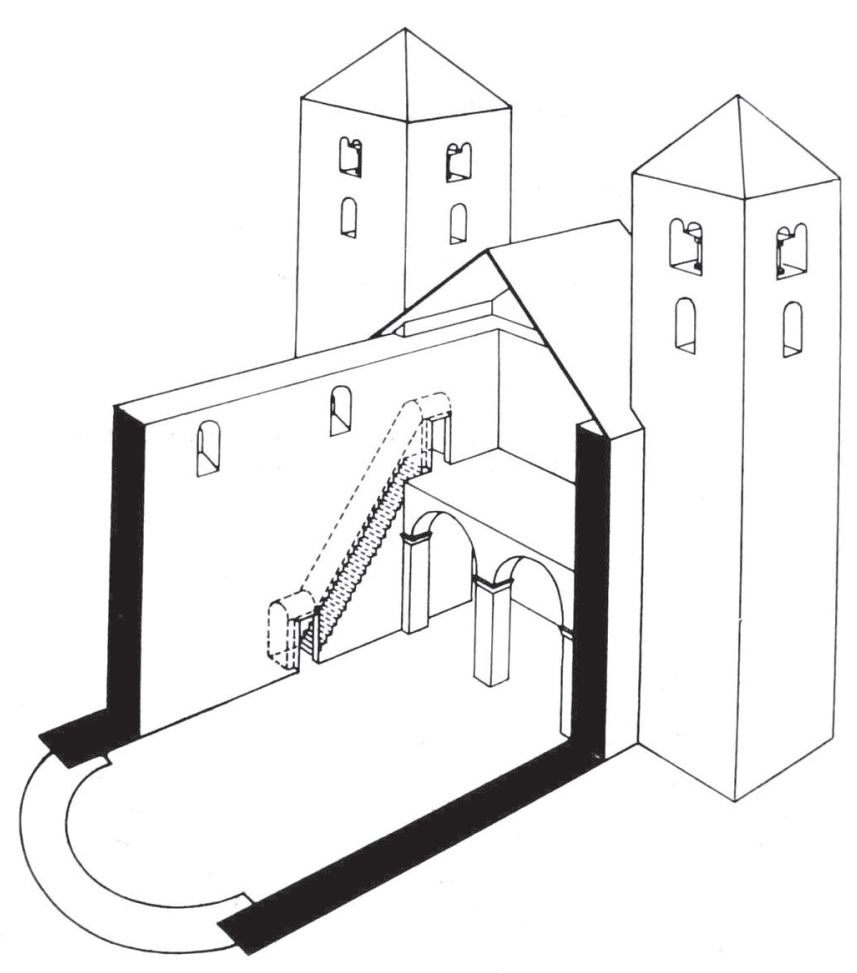

fundamentem południowej wieży i ścianą prezbiterium, a także różnice w obróbce powierzchni ciosów oraz odnaleziono fragment pilastra podpierającego emporę ${ }^{10}$. Te ustalenia wykorzystała Elżbieta Dąbrowska, rozwarstwiając budowlę na dwie fazy, datowane za początkowymi sugestiami Tomaszewskiego na wiek XII (I faza) i XIII (II faza) ${ }^{11}$. Kolejne argumenty do dyskusji wniosła konserwacja ściany północnej prezbiterium w 1965 r., w wyniku której odkryto dwa romańskie okna, portal wiodący na emporę oraz odcisk jej sklepienia i parapetu. Odkrycia te w swoich badaniach uwzględniła Maria Pietrusińska ${ }^{12}$. Ostatecznie Andrzej Tomaszewski ustalił, że kościół powstał najprawdopodobniej w 1. połowie XII w. i składał się z nawy o długości około 20 metrów, zamkniętej od wschodu półkolistą absydą, a od zachodu dwuwieżową fasadą z emporą otwierającą się do wnętrza świątyni (il. 2). Badacz zasugerował, że w początkowej fazie budowy kościół miał składać się tylko z korpusu zamkniętego od wschodu półkolistą absydą i z zachodnią emporą, do którego następnie dostawiono dwie wieże. Miałoby to nastąpić w wyniku zmiany koncepcji w trakcie wznoszenia świątyni, choć autor nie wykluczał też możliwości, że zachodnią część przebudowano w jakiś czas po wystawieniu kościoła ${ }^{13}$. Ustalenia Tomaszewskiego utrwaliły się w literaturze przedmiotu (jednak z szerokim datowaniem na XII w.); wyjątkiem jest tylko praca Ewy Kubicy, gdzie powtórzono tezy Dąbrowskiej ${ }^{14}$.

\footnotetext{
${ }^{10}$ Wojewódzki Urząd Ochrony Zabytków w Kielcach, Ewidencja Dokumentacji Naukowo-Technicznej, sygn. BA 48: Skalbmierz, kościót św. Jana Chrzciciela. Fotografie. 1963 r.

${ }^{11}$ Elżbieta DĄBrowska, Studia nad osadnictwem wczesnośredniowiecznym Ziemi Wiślickiej (Wrocław: Ossolineum, 1965), s. 249-250.

12 Maria PietrusińskA, „Skalbmierz”, w: Sztuka polska przedromańska i romańska do schyłku XII wieku, red. Michał WALICKI (Warszawa: PWN, 1971), s. 755-756 (Dzieje sztuki polskiej, 1).

${ }^{13}$ Tomaszewski, Romańskie kościoły z emporami zachodnimi, s. 115-119.

${ }^{14}$ Ewa KubICA, „Katalog zabytków wczesnośredniowiecznej architektury monumentalnej Małopolski, Rusi Halickiej i Wołynia”, Materiały i Sprawozdania Rzeszowskiego Ośrodka Archeologicznego 17 (1996), s. 164-165; Zygmunt ŚwIECHowski, Architektura romańska w Polsce (Warszawa: DiG, 2000), s. 221-222; ID., Katalog architektury romańskiej
} 


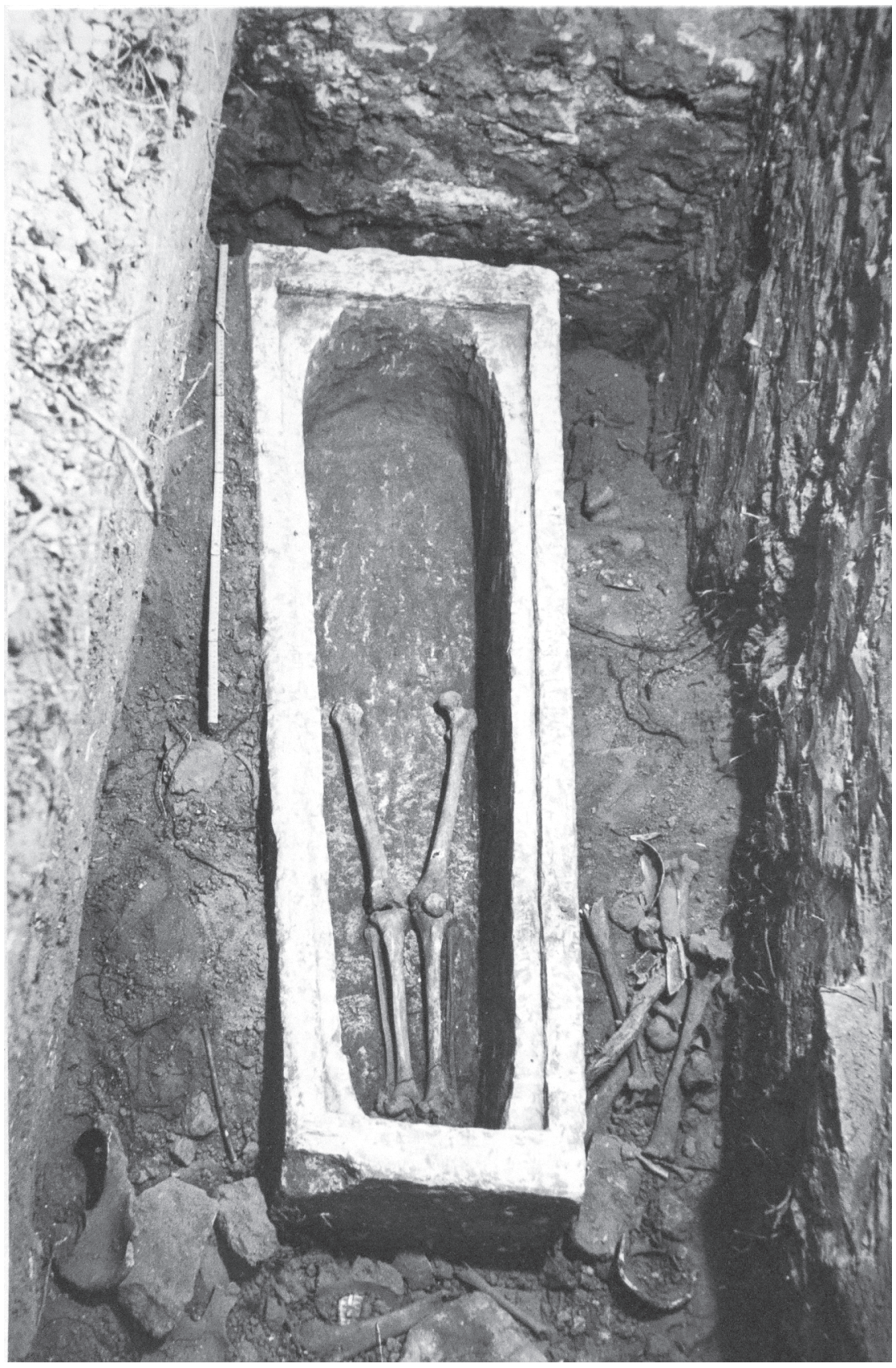

3. Sarkofag odkryty za wschodniq ściana kościoła św. Jana Chrzciciela w Skalbmierzu, WUOZ w Kielcach, Ewidencja Dokumentacji Naukowo-Technicznej, sygn. BA 48

Od lat 60. XX w. nie przeprowadzono w Skalbmierzu regularnych badań, a sondażowe wykopy wykonane w ramach prac odwadniających nie przyniosły odkryć, które mogłyby radykalnie wpłynąć na przyjętą w literaturze interpretację. Jednak zarówno one, jak i weryfikacja starszych ustaleń $\mathrm{w}$ połączeniu $\mathrm{z}$ aktualną wiedzą na temat funkcjonowania kanonii skalbmierskiej i samego miasta skłaniają do sformułowania kilku uwag.

w Polsce (Warszawa: DiG, 2009), s. 432-433; Dethard von Winterfeld, Christofer Herrmann, „Kleinpolen”, w: Mittelalterlische Architektur in Polen. Romanische und Gotische Baukunst zwischen Oder und Weichsel, red. Dethard von Winterfeld, Christofer Herrmann (Petersberg: Michael Imhof, 2015), s. 415. 


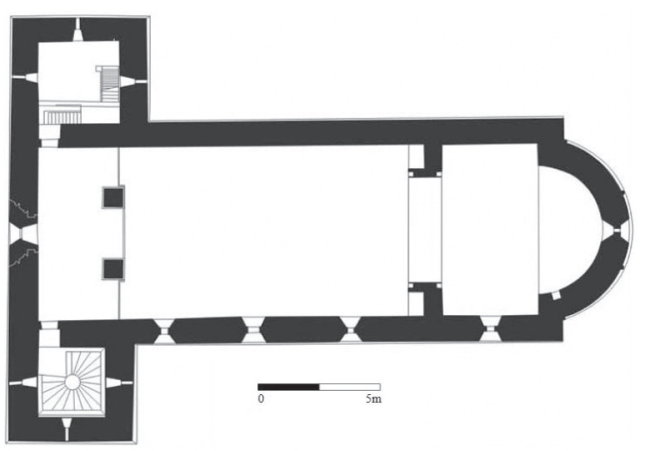

\author{
4. Plan kościoła św. Jana Chrzciciela \\ w Rimavských Janovciach. Repr. za: Bibiana \\ Pomfyová, Ranostredoveké kláštory na \\ Slovensku: torzálna architektúra - torzálne \\ poznatky - torzálne hypotézy, s. 746
}

Nie budzi wątpliwości rekonstrukcja zachodniej części skalbmierskiego kościoła. Wieże, a przynajmniej południowa, do której fundamentów był dostęp, została dostawiona do istniejącej juź ściany lateralnej pierwotnej nawy (obecnego prezbiterium), przy czym wydaje się, że nastąpiło to jeszcze w trakcie wznoszenia murów świątyni. Do takiego wniosku skłania przewiązanie wyższych partii murów obydwu kompartymentów. Ponadto widoczne różnice w obróbce ciosów - te, z których zbudowana jest wieża, mają charakterystyczny sposób wykończenia w tzw. jodełkę, pozostałe są szlifowane na gładko - nie są argumentem rozstrzygającym o późniejszym wykonaniu czy zmianie warsztatu. W innych zachowanych fragmentach kościoła są one bowiem przemieszane, co widoczne jest w ościeżach okien na północnej ścianie i przylegającej do niej wieży. Również we wnętrzu wieży południowej znajdują się ciosy o innym niż jodełkowe sposobie opracowania lica. Ponadto w ościeżach gotyckiego okna w ścianie południowej znajduje się cios opracowany w jodełkę, wykorzystany tam wtórnie, a pochodzący najprawdopodobniej z pierwotnego okna. Również kształt empory jest stosunkowo dobrze czytelny, zachował się portal łączący ją z wieżą północną oraz odciski sklepienia i niskiego murku zamykającego platformę od wschodu. Na wewnętrznej powierzchni ściany południowej wyraźnie widoczne jest też miejsce po portalu, łączącym poprowadzone w grubości ściany schody z emporą. Natomiast nie jest jasne, na czym oparte zostało twierdzenie Dąbrowskiej, że wraz z dobudową wież uległa likwidacji empora.

Więcej kontrowersji budzi forma wschodniej części kościoła. Tomaszewski zrekonstruował ją jako półkolistą absydę zlokalizowaną wewnątrz obrysu obecnego poligonalnego zamknięcia. Twierdzenie to oparte jest na sondażowym wykopie przeprowadzonym za wschodnią ścianą prezbiterium, w którym nie ujawniono fundamentów wyznaczających granicę budowli. Natrafiono natomiast na kamienny sarkofag wykuty z jednego bloku wapienia, określany jako romański, a zlokalizowany na osi kościoła, tuż za wschodnią ścianą (na il. 1 oznaczony jako A; il. 3) ${ }^{15}$. Zarówno usytuowanie, jak i forma pochówku budzą nieodparte skojarzenia z uprzywilejowanymi grobami lokalizowanymi in medio chori $^{16}$. Podobnie w wykutych z jednego kawałka skały sarkofagach umieszczonych w prezbiterium, pochowano członków dynastii salickiej w katedrze w Spirze ${ }^{17}$ oraz Wratysława II

\footnotetext{
${ }^{15}$ Helena Zoll-Adamiкowa, Wczesnośredniowieczne cmentarzyska szkieletowe Małopolski, cz. 2: Analiza (Wrocław: Ossolineum, 1971), s. 183; DĄBrowskA, Studia nad osadnictwem wczesnośredniowiecznym Ziemi Wiślickiej, s. 249.

${ }^{16}$ Literaturę zebrały Marta Graczyńska i Monika Kamińska. Zob. Marta GraczYŃSKA, Monika KamińsKA, „Reqiuescat in pace. Uprzywilejowane miejsca pochówku w architekturze środkowoeuropejskiej w X-XI wieku. Studium przypadku”, w: Architektura w poczatkach państw Europy Środkowej, red. Tomasz JaniaK, Dariusz StryniaK (Gniezno: Muzeum Początków Państwa Polskiego, 2018), s. 354-359.

${ }^{17}$ Caspar EhLERs, „Die Salischen Kaisergräber im Speyerer Dom”, w: Die Salier: Macht im Wandel: Essays, red. Laura HeEg (München: Minerva, 2011), s. 203-209.
} 


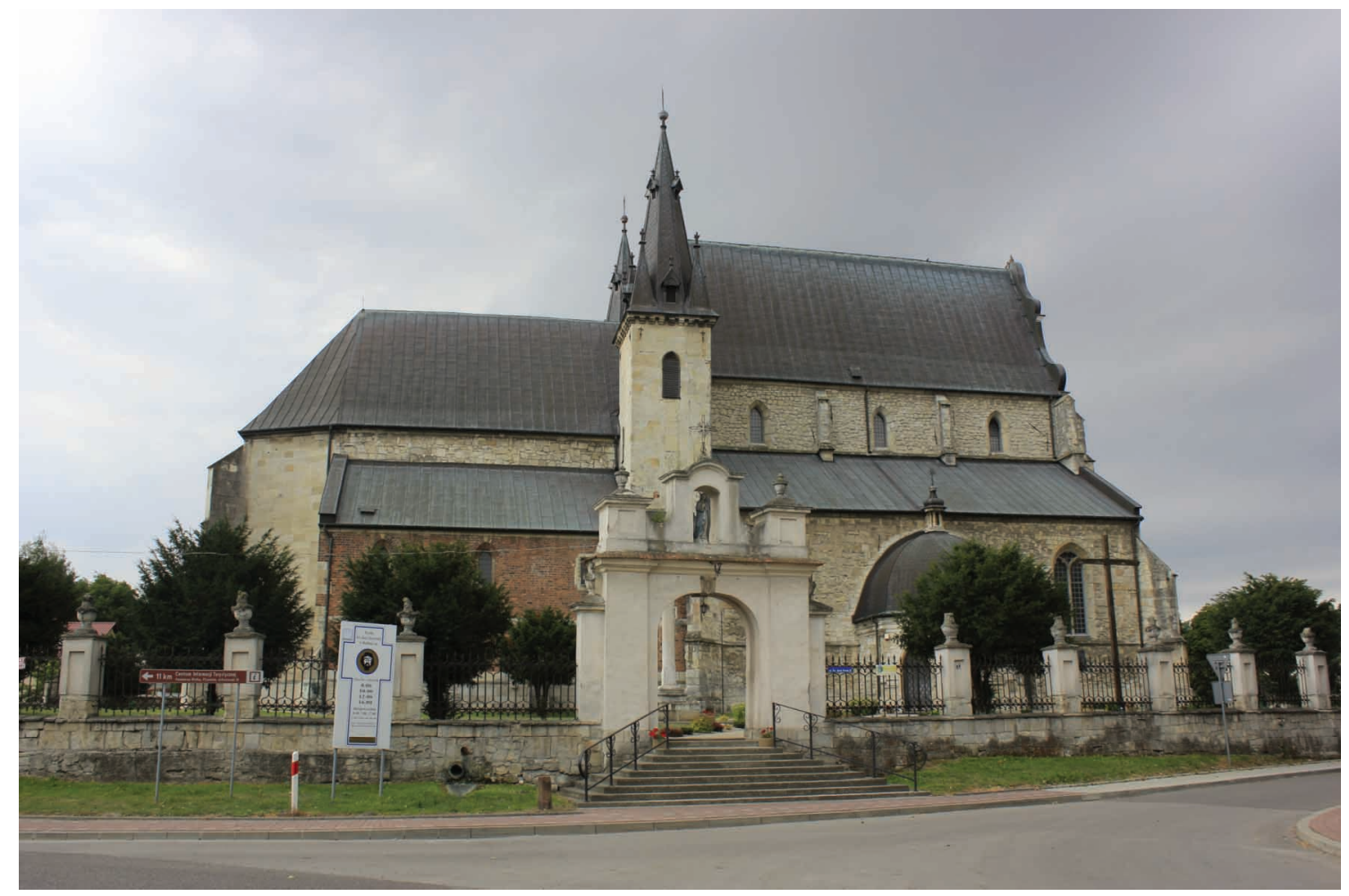

5. Kościót św. Jana Chrzciciela w Skalbmierzu, widok od pótnocy. Fot. Andrzej Otrębski

na Wyszehradzie ${ }^{18}$. Ponadto w zapisie o zniszczeniach wywołanych przez trzęsienie ziemi w 1443 r. wyraźnie mowa jest o uszkodzeniu sklepienia: ,in Scarbimiria pars templi et testitudo a loco mota est” ${ }^{19}$. Z kolei Długosz zaświadcza, że „Scarbimiriensem ecclesiam [...] pulcherrimo muro novo, veteri abrogato, ex pecunia devotione fidelium congesta, in diebus nostris fabricata" ${ }^{20}$. Zważywszy, że na zachowanych niemal w pełnej wysokości ścianach romańskiego kościoła nie widać śladów po sklepieniach, a obecny korpus nawowy powstał, jak się wydaje, po katastrofie z roku 1443, po wschodniej stronie świątyni należy się domyślać fragmentu nierozpoznanego dotychczas, a pochodzącego sprzed tej daty. Budowla miałaby wtedy plan i wymiary identyczne jak datowany na 2. połowę XII w. benedyktyński kościół w Rimavských Janovciach (il. 4) ${ }^{21}$. Natomiast wspomniany pochówek znalazłby się w absydzie, podobnie jak to miało miejsce w przypadku grobu nr 199 w kościele św. Piotra w Sárvármonostor ${ }^{22}$. Do koncepcji o pierwotnie większych rozmiarach skalbmierskiego kościoła skłaniać może także fakt, że pełnił on funkcję fary.

\footnotetext{
${ }^{18}$ Miroslav Šmied, Praga Sacra. K vizi posvátné Prahy císaře Karla IV. a jejím duchovním kořenům (Praha: Univerzita Karlova v Praze, 2018), s. 68.

${ }^{19}$ Cracovia Artificum: Supplementa. Teksty źródłowe do dziejów kultury i sztuki z archiwaliów kurialnych i kapitulnych w Krakowie 1441-1450, oprac. Bolesław PrzyByszewski (Kraków: Secesja, 1993), s. 103. Słowo testitudo mogło oznaczać również dach, jednak w tej samej notatce, zdanie wcześniej, użyto go na określenie sklepień w kościele św. Katarzyny na Kazimierzu. Pozwala to z dużym prawdopodobieństwem przyjąć taką interpretację tego terminu.

${ }^{20}$ Jan DŁugosz, Liber beneficiorum dioecesis Cracoviensis, t. 1, oprac. Aleksander PrzEźDZIECKI (Kraków: [s. n], 1864), s. 516.

${ }^{21}$ Tomaszewski, Romańskie kościoły z emporami zachodnimi, s. 270; Martin HanUŠ, David KuŠNiRÁK, Michal SLIVKA, „Výsledky geofizikálneho výskumu zaniknutého benediktínskeho kláštora v Rimavských Janovciach”, Archeologia Historica 42, nr 2 (2017), s. 652.

${ }^{22}$ GracZyŃSKA, KAMIŃSKA, „Reqiuescat in pace”, s. 336-337.
} 


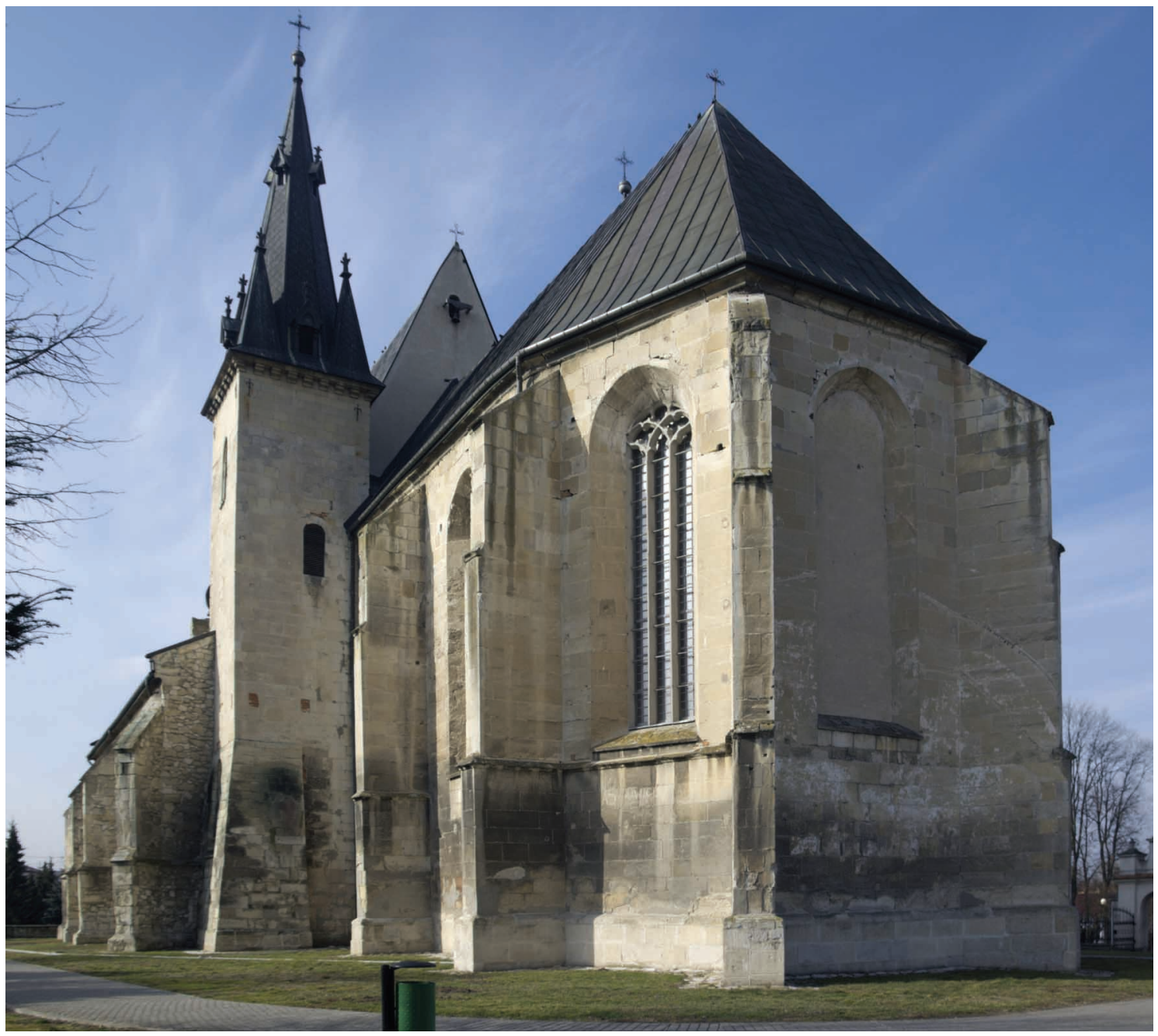

6. Kościót św. Jana Chrzciciela w Skalbmierzu, widok od potudniowego-wschodu. Fot. Jakub Hałun

Choć trudno oszacować wielkość miasta na początku XIII w., wymowny jest fakt, że Konrad Mazowiecki zdecydował się ufortyfikować skalbmierski kościół pomimo bardzo niekorzystnego (ze względu na otaczające go wzgórza) położenia. Tutaj odbył się zjazd małopolskich panów w 1243 r. , a w 1254 r. kolegiata objęta została - na równi z katedrą krakowską i kolegiatami w Wiślicy i Kielcach - przywilejem wydanym przez Bolesława $\mathrm{Wstydliwego}^{23}$. Sama kapituła skalbmierska liczyła w tym czasie przynajmniej pięciu kanoników ${ }^{24}$. Zatem miasto musiało być ważnym i ludnym ośrodkiem w Małopolsce jednym $\mathrm{z}$ najgęściej zasiedlonych regionów ówczesnej Polski ${ }^{25}$. Powyższe przesłanki oczywiście nie wystarczą, aby uznać, że rekonstrukcja Tomaszewskiego jest błędna, niemniej, w mojej opinii, są one poważnym argumentem za podjęciem kompleksowych badań archeologicznych w i wokół skalbmierskiego kościoła.

XV-wieczna przebudowa, która nadała kościołowi jego dzisiejszą postać, cieszyła się jeszcze mniejszym zainteresowaniem badaczy. Kotarbiński podał, że obecny kościół

\footnotetext{
${ }^{23}$ Stanisław Romanowski, „Dzieje miasta Skalbmierza”, Rocznik Muzeum Świętokrzyskiego 3 (1965), s. 223 i n.

${ }^{24}$ SzYmański, Kanonikat świecki w Małopolsce od końca XI do połowy XIII wieku, s. 119.

${ }^{25}$ Romanowski, „Dzieje miasta Skalbmierza”, s. 216.
} 
powstał na miejscu starego około 1440 r., co powtórzył Wiśniewski ${ }^{26}$. Łuszczkiewicz jako pierwszy trafnie rozpoznał inspiracje krakowskimi wzorami, datując budynek na początek XV w. ${ }^{27}$ Natomiast Chlebowski stwierdził, że prezbiterium wystawiono w XV, a korpus nawowy w XVII w. ${ }^{28}$ Badaniom architektonicznym poddał świątynię dopiero Adolf Szyszko-Bohusz. Analiza doprowadziła go do wniosku, że kościół powstał w początkach XV w., a proporcje nawy oraz sposób profilowania arkad międzynawowych są analogiczne do tych w katedrze na Wawelu i innych krakowskich bazylikach. Ustalił również, że sklepienie wykonano w XVII w. (być może około roku 1638), wcześniej zaś kościół był kryty stropem lub miał otwartą więźbę dachową. Ponadto wskazał, że łuk tęczowy ma profilowanie rozpoczynające się od poziomu opaski cokołowej, a zakrystia miała kiedyś szczyt wschodni dekorowany sterczynami i dach zintegrowany z przekryciem prezbiterium. Zauważył też brak niektórych maswerków. Warto zaznaczyć, że badacz ocenił znacznie wyżej wartość artystyczną architektury skalbmierskiej kolegiaty niż omówionych w tym samym artykule kościołów w Beszowej i Bodzentynie ${ }^{29}$. Szydłowski określił kolegiatę krótko jako gotycką ${ }^{30}$, natomiast Kutrzebianka wydzieliła trzy fazy budowy - najpierw w 1. połowie XV w. miał powstać korpus nawowy, następnie w końcu tego stulecia prezbiterium, a z początkiem XVI w. zakrystia ${ }^{31}$. Z kolei Paul Crossley datował całość na 2. ćwierć XV w. ${ }^{32}$ Paweł Pencakowski i Andrzej Włodarek opowiedzieli się za teza, że korpus powstał w 3. ćwierci a prezbiterium w końcu XV stulecia, natomiast zakrystia na przełomie XV i XVI w. ${ }^{33}$ Grzybkowski, podobnie jak Crossley, nie wydzielił osobnych faz budowy, całość zadatował jednak na 3. ćwierć XV w. ${ }^{34} \mathrm{Z}$ kolei Dethard von Winterfeld i Christofer Herrmann stwierdzili, że kolegiatę przebudowano pomiędzy rokiem 1443 (trzęsienie ziemi) a 1470 (na który to rok badacze datują przytoczoną wyżej wzmiankę Długosza) ${ }^{35}$. Warto zauważyć, że w żadnym z tekstów, poza artykułem Szyszko-Bohusza, nie znalazła się wychodząca poza ogólniki analiza skalbmierskiego kościoła.

Omawiana kolegiata składa się z trójnawowego i trójprzęsłowego korpusu (z łamanego kamienia) w układzie bazylikowym, w tzw. systemie krakowskim, bez łuków oporowych, z przyporami wspierającymi nawę główną, dostawionymi do filarów i wydłużonego trójprzęsłowego chóru (z ciosów, w technice opus emplectum) z poligonalnym, trójbocznym zamknięciem (il. 5-6). Na wschodnich krańcach naw bocznych znajdują się wieże (również z ciosów). Kościół ma zakrystię przylegającą do północnej ściany prezbiterium oraz dwa wejścia osłonięte kruchtami: północne pięcioboczną a zachodnie czworoboczną. Elewacje zewnętrzne na całym obwodzie, z wyjątkiem wieży południowej, dwóch zachodnich przęseł południowej ściany prezbiterium i fragmentów krucht, obiega cokół

\footnotetext{
${ }^{26}$ KotARBIŃSKI, „Historyczna wiadomość o kolegiacie szkalbmierskiej”, s. 409; WiŚNIEWSKI, Historyczny opis kościołów, miast, zabytków i pamiątek w pińczowskiem, skalbmierskiem i wiślickiem, s. 386.

${ }^{27}$ ŁuszczKIEwICZ, „Kościół pokolegijacki w Szkalbmierzu”, s. 29.

${ }^{28}$ ChleBowski, ,Skalbmierz”, s. 638.

29 Adolf Szyszкo-Bohusz, „Beszowa, Skalbmierz i system krakowski”, Sprawozdania Komisyi do Badania Historyi Sztuki w Polsce 9, z. 1 (1913), kol. 66-79.

${ }^{30}$ SzYDŁowski, Pomniki Architektury epoki piastowskiej we województwach krakowskiem i kieleckiem, s. 35.

31 „Skalbmierz”, w: Katalog Zabytków Sztuki w Polsce, s. 83; OlczaK, Olszewski, Parafia Skalbmierz, s. 69.

32 Paul Crossley, Gothic Architecture in the Reign of Kasimir the Great: Church Architecture in Lesser Poland 13201380 (Kraków: Ministerstwo Kultury i Sztuki, Zarząd Muzeów i Ochrony Zabytków, 1985), s. 89.

${ }^{33}$ Paweł Pencakowski, Andrzej WŁodAreK, „Skalbmierz”, w: Architektura gotycka w Polsce, t. 2, red. Teresa Mroczko, Marian ArszYŃski (Warszawa: Instytut Sztuki PAN, 1995), s. 206 (Dzieje sztuki polskiej, 2).

${ }^{34}$ GrZYBKowsKi, Gotycka architektura murowana w Polsce, s. 169.

${ }^{35}$ Winterfeld, HerrmanN, ,Kleinpolen”, s. 415.
} 


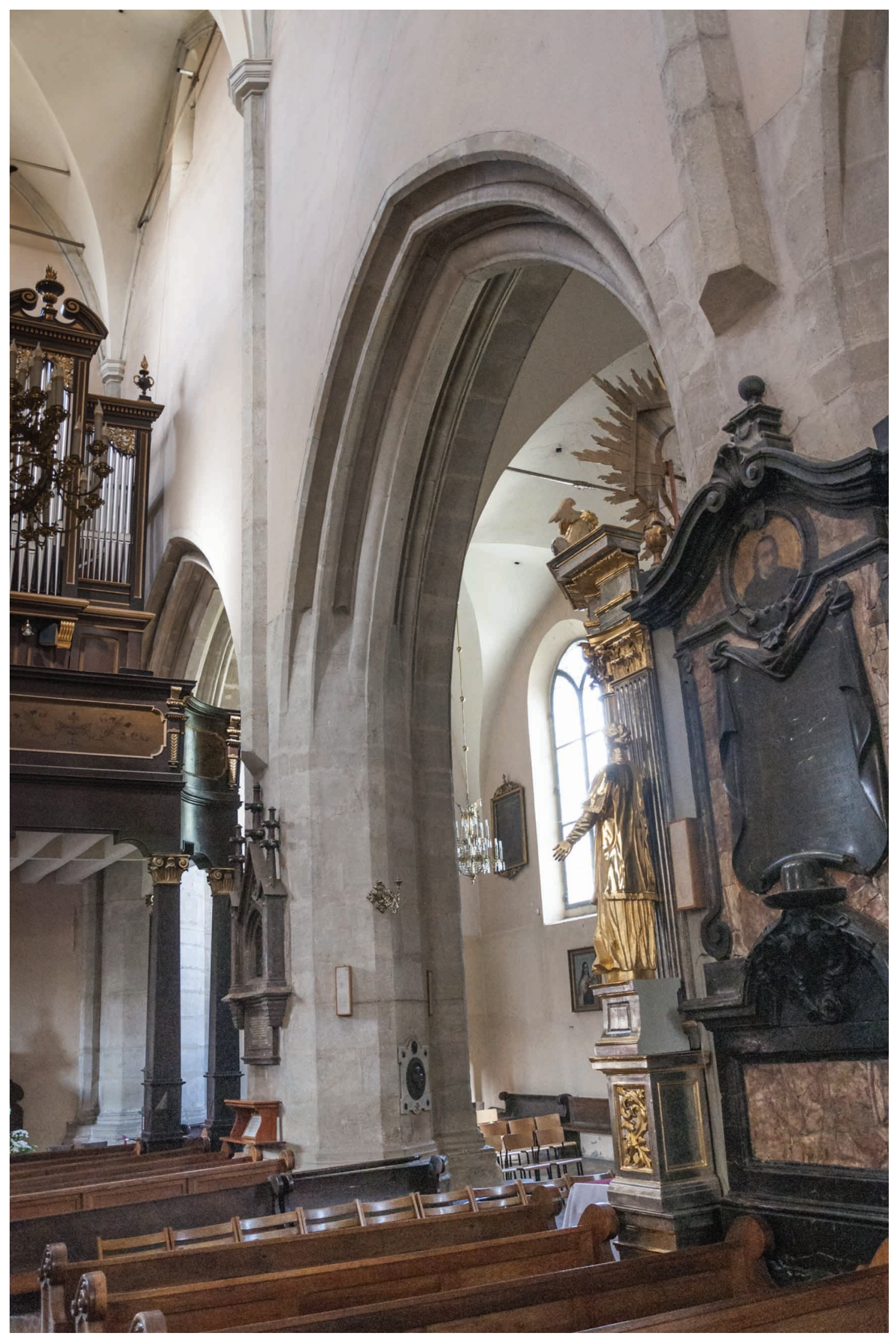

7. Kościót św. Jana Chrzciciela w Skalbmierzu, wnętrze korpusu nawowego.

Fot. Wojciech Sowata 


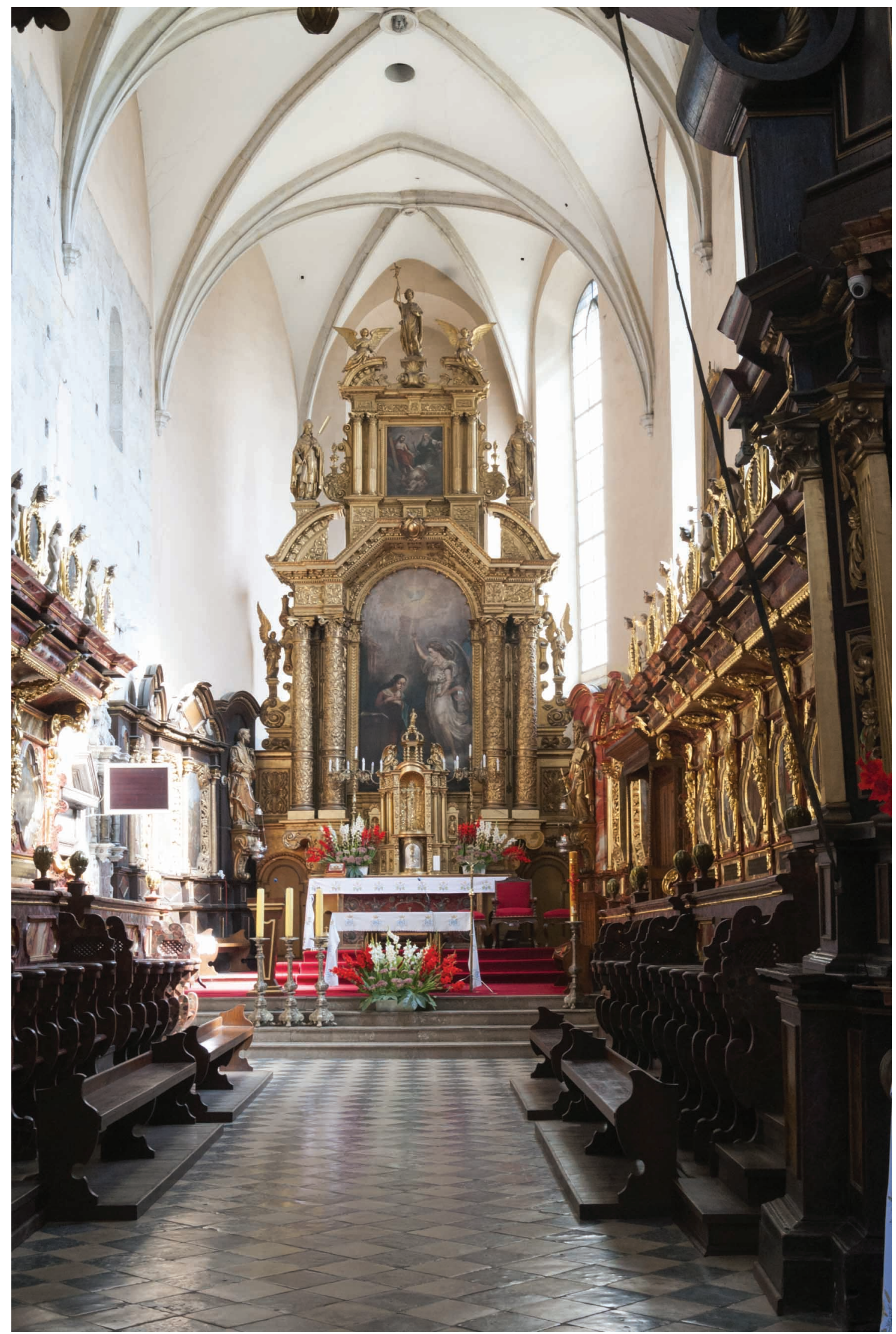

8. Kościót św. Jana Chrzciciela w Skalbmierzu, wnętrze prezbiterium. Fot. Wojciech Sowała 


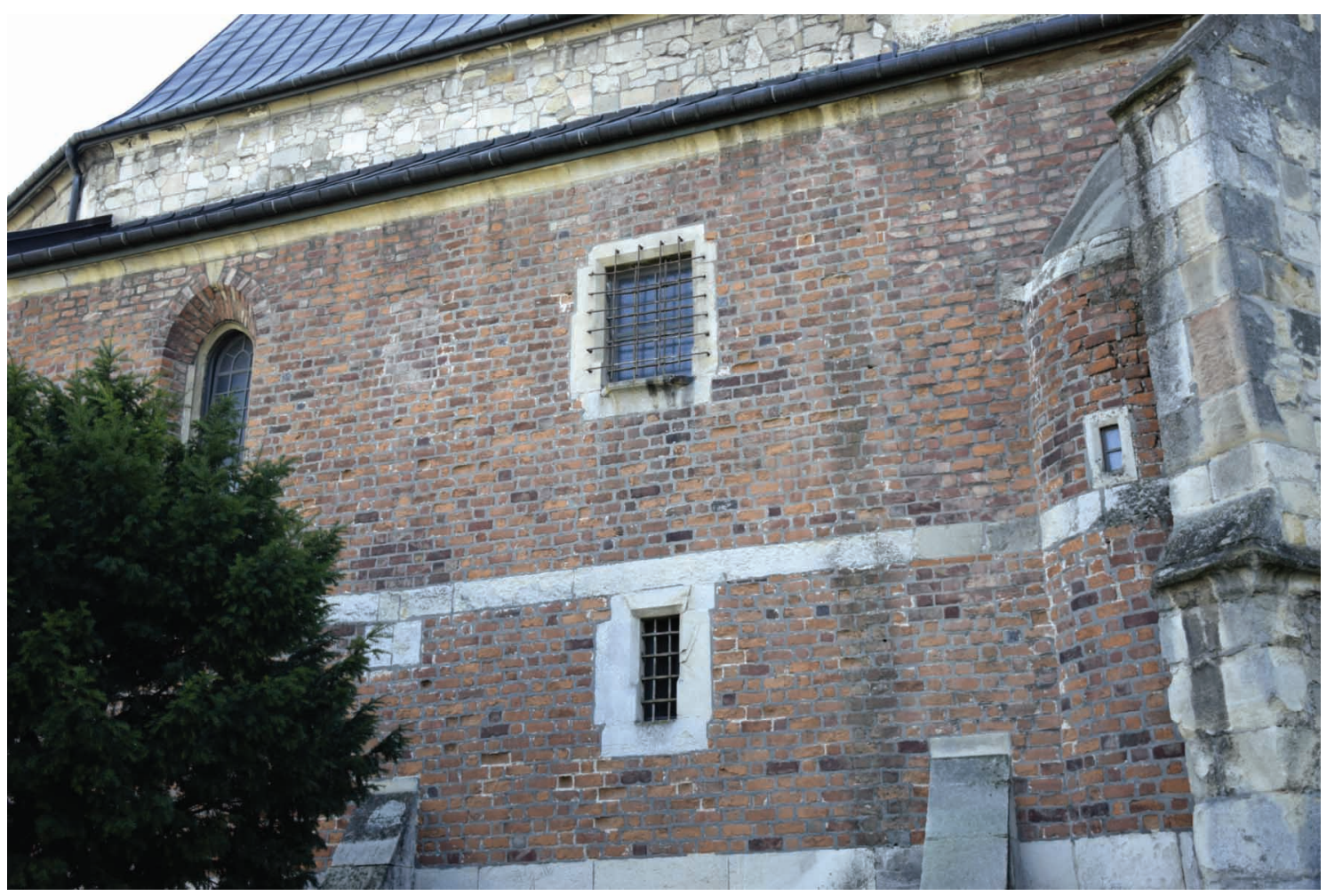

9. Kościót św. Jana Chrzciciela w Skalbmierzu, zakrystia. Fot. Wojciech Sowata

i gzyms kapnikowy (na zakrystii skuty). Budynek opięty jest przyporami, z których zrezygnowano jedynie w wypadku północnej ściany prezbiterium i środkowej partii ściany lateralnej północnej nawy, natomiast przy zakrystii zrealizowano jedynie dolne partie przypór, sięgające nieco ponad partię cokołową. Wnętrze korpusu nawowego podzielone jest za pomocą rzędów arkad wspartych na filarach. Gładkie, wykonane z precyzyjnie dopasowanych ciosów piaskowca filary wsparte są na profilowanym cokole. Podłucza arkad dekorują mięsiste, głęboko cięte profile. W nawie głównej elewacje wewnętrzne ozdobione są tylko za pomocą wielobocznych, wtopionych w ścianę, nadwieszonych służek i żeber tarczowych (il. 7). Oświetlenie zapewnia sześć niewielkich ostrołukowych okien w ścianach bocznych i nieco większe okno w fasadzie. Nawy boczne doświetlone są za pomocą pięciu okien (obecnie jedno zamurowane) i nie posiadają dekoracji architektonicznej. Wszystkie nawy przekryte są sklepieniami krzyżowo-kolebkowymi. Łuk tęczowy ma identyczne jak podłucza arkad międzynawowych profilowanie, z tą różnicą, że wychodzi ono od poziomu partii cokołowej, za wyjątkiem fragmentu w części południowej od strony nawy, gdzie rozpoczyna się wyżej, na trudnej do ustalenia wysokości. Prezbiterium przekryte jest sklepieniem krzyżowo-żebrowym (z żebrami wspartymi na wielobocznych konsolach, złożonych z kilku warstwowych segmentów o wklęsłych ściankach) i doświetlone trzema zamkniętymi niemal półkoliście wielkimi oknami w ścianie południowej. Okno czwarte, obecnie zamurowane, znajdowało się od wschodu. Przecięcia żeber są dekorowane zwornikami z głową Jana Chrzciciela i mitrą biskupią oraz dwoma pozbawionymi dekoracji. Mniejsze, również gładkie zworniki umieszczono w kluczach środkowych żeber jarzmowych (il. 8). W wieży południowej znajduje się kaplica połączona z nawą południową gładką arkadą. Podobna arkada, obecnie zamurowana, łączyła kaplicę z prezbiterium. Krzyżowo-żebrowe sklepienie kaplicy oparte jest na żebrach bezpośrednio wnikających w ścianę i pozbawione zwornika. 


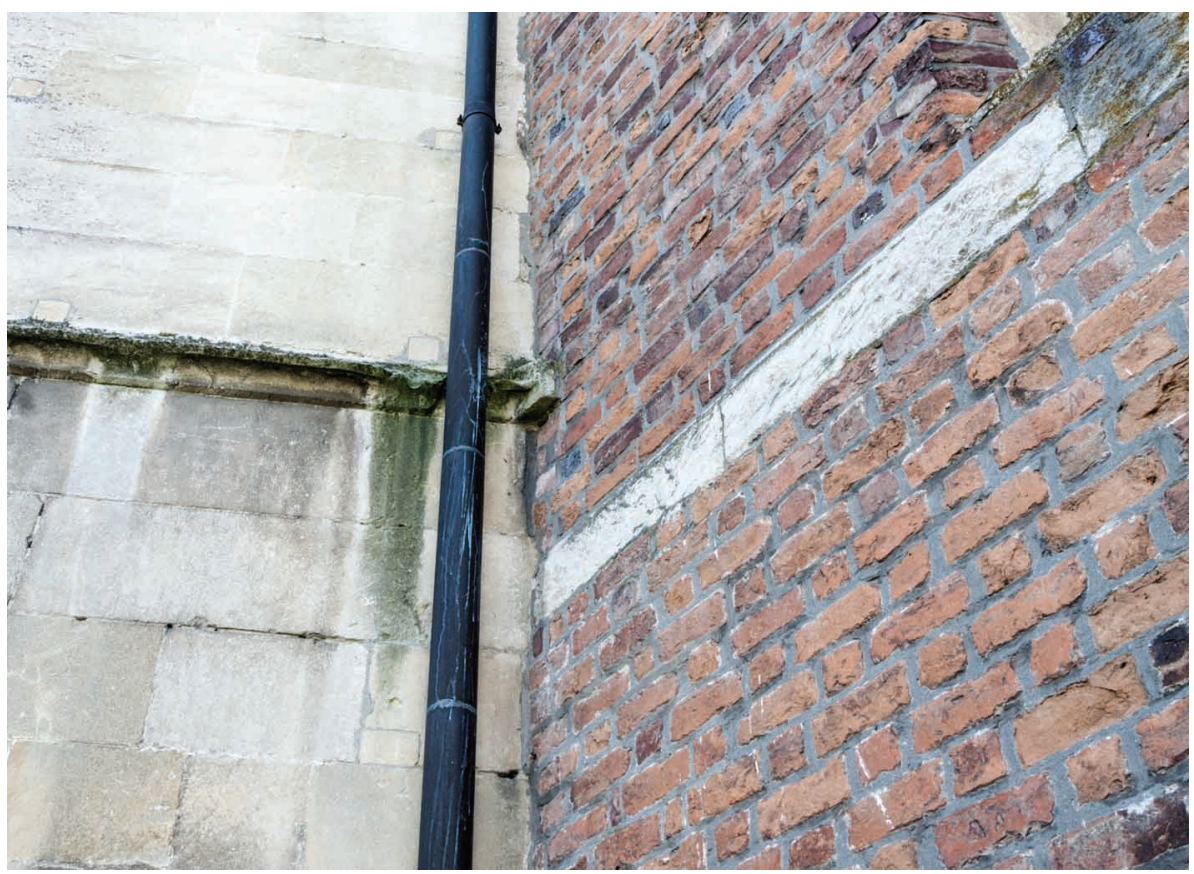

10. Kościót św. Jana Chrzciciela w Skalbmierzu, gzyms kapnikowi na styku ścian prezbiterium i zakrystii. Fot. Wojciech Sowała

Zakrystia (ceglana za wyjątkiem partii cokołowej) składa się z dwóch części (i1. 9). Pierwsze dwuprzęsłowe pomieszczenie - ze sklepieniem krzyżowo-żebrowym bez zworników, z żebrami wspartymi na nadwieszonych konsolach o podobnym, lecz uproszczonym kształcie jak w prezbiterium - doświetlone jest trzema ostrołukowymi oknami. Druga część - podzielona na dwa przesklepione kolebkowo i połączone klatką schodową poziomy - doświetlona jest prostokątnymi oknami. W przyziemiu wieży północnej znajduje się przesklepione kolebkowo pomieszczenie bez okien.

Włączenie w XVI w. dochodów prepozytury skalbmierskiej do uposażenia wikariuszy katedry krakowskiej i postępujący upadek miasta po potopie szwedzkim spowodował, że gotycki kościół przekształcono tylko w niewielkim stopniu ${ }^{36}$. W XVII w. założono sklepienia $\mathrm{w}$ nawach, dobudowano kruchtę zachodnią, zmieniono okno $\mathrm{w}$ fasadzie i szczyt zachodni nawy głównej ${ }^{37}$. Zapewne też $\mathrm{w}$ tym czasie zmodernizowano okna w prezbiterium, zwieńczenie zamykając łukiem pełnym i podnosząc poziom parapetów. W 1. połowie XVIII w. prowadzono prace przy wieżach i prawdopodobnie wtedy dostawiono skarpy do wieży południowej. W latach 70. XIX w., staraniem proboszcza Wincentego Gasińskiego, wykonano remont okien w nawach i prezbiterium, wymieniono okna i hełmy wież na neogotyckie oraz przekształcono kruchtę północną. W trakcie prac w latach 19491952 skuto tynki, przy czym nie wydaje się, aby faktycznie, jak twierdzi Kutrzebianka, przemurowano lica - odsłonięte partie murów, widoczne na zdjęciach z początku XX w., wyglądają identycznie jak obecnie ${ }^{38}$.

\footnotetext{
${ }^{36}$ RomanowsKi, „Dzieje miasta Skalbmierza”, s. 241-243.

${ }^{37} \mathrm{~W}$ wizytacji z 1610 r. zapisano, że prezbiterium przekryte jest sklepieniem, a nawy płaskim stropem. Jest zatem wysoce prawdopodobne, że w XV w. nie zdołano zasklepić nawy, choć, jak wskazuje wystawienie przypór i zastosowana artykulacja ścian, było to w planach. Archiwum Kurii Metropolitalnej w Krakowie (dalej: AKMK), AVCap. 28: Acta visitationis exterioris decanatus Witoviensis, Opatovecnsis, Skavinensis, Zatoriensis, Kiiensis, Oswencimensis, Wolbromensis, Skalensis, Pacanoviensis et Sokoliensis authoritate Petri Tylicki ep. Crac. [...] a.D. 1610 facta, k. 351r.

38 „Skalbmierz”, w: Katalog Zabytków Sztuki w Polsce, s. 83.
} 
11. Kościót św. Jana

Chrzciciela w Skalbmierzu, styk ścian pótnocnej nawy $i$ kruchty. Fot. Wojciech Sowata

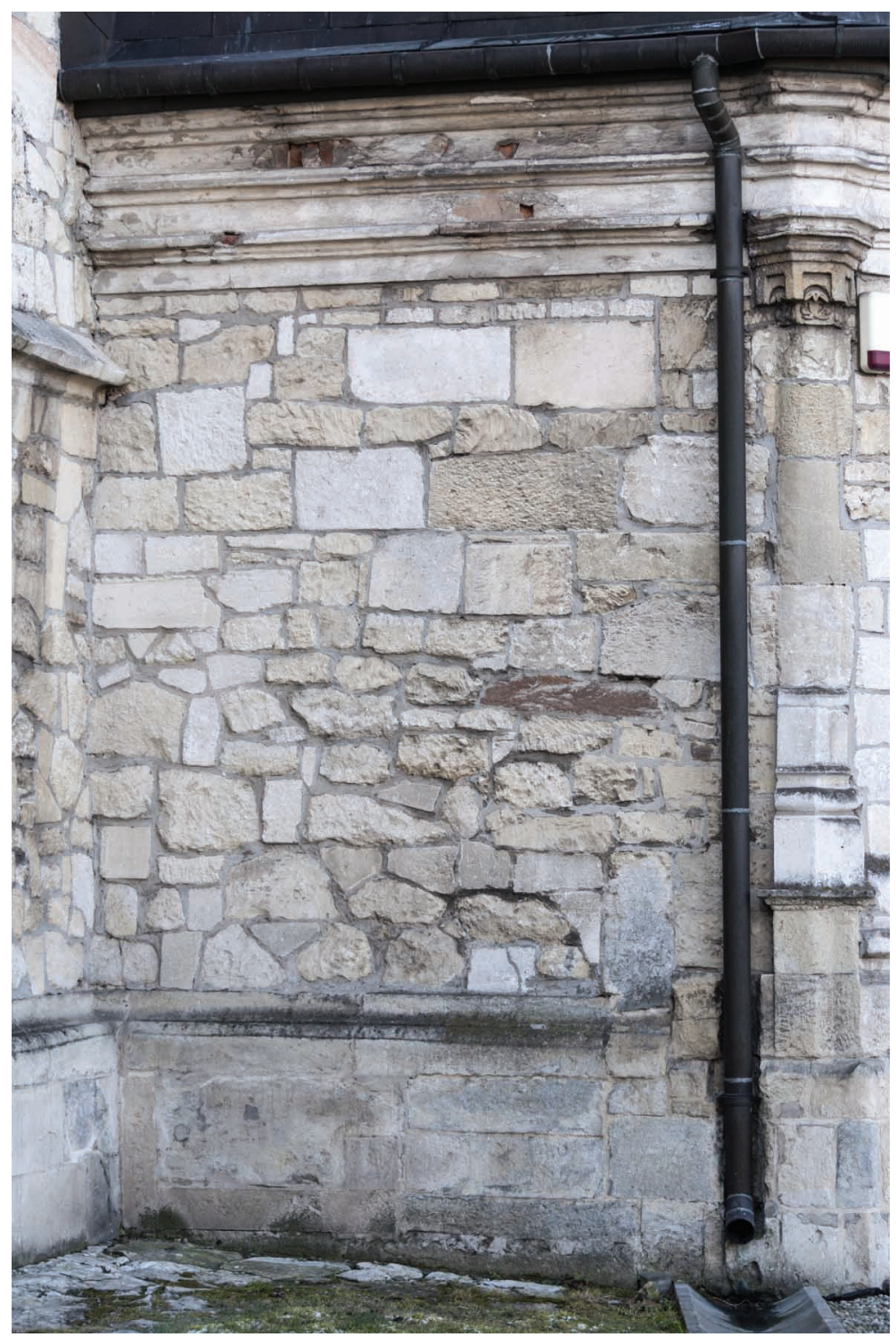

Pomimo różnego materiału zastosowanego przy wznoszeniu kolejnych części kościoła, trudno jest wydzielić wyraźne fazy budowy czy zmiany warsztatów. Gzymsy (koronujący, kapnikowe oraz cokołowe) mają bardzo zbliżone profile na całym obwodzie budynku. Górna, nadbudowana część ściany prezbiterium wykonana jest w takiej samej technice jak korpus nawowy, zakrystia, pomimo że ceglana, w partii cokołowej jest zbudowana z ciosów, a kształtka gzymsu kapnikowego załamuje się, łącząc ściany prezbiterium i zakrystii (il. 10). Co więcej, kruchta północna, dotychczas datowana na XIX w. ${ }^{39}$ i zapewne wtedy przebudowana do obecnej formy, wydaje się być starsza. Wskazuje na to jednolicie opracowana partia cokołowa, obejmująca ścianę północnej nawy oraz wschodnią i zachodnią ścianę kruchty (il. 11). Ponadto ściany te wypadają dokładnie na granicy przęseł i pełnią rolę przypór, zatem kruchtę (choć w innej formie niż obecna) wzniesiono prawdopodobnie razem z korpusem nawowym. Dodatkową przesłanką, potwierdzająca starszą niż XIX w. metrykę tej części kościoła, jest opis z 1791 r., w którym została ona wspomniana $^{40}$.

\footnotetext{
${ }^{39}$ Ibid., s. 83.

${ }^{40}$ AKMK, APB 169: Opisanie stanu kościoła Kollegiaty Szkalmierskiej...1791, k. 25r.
} 


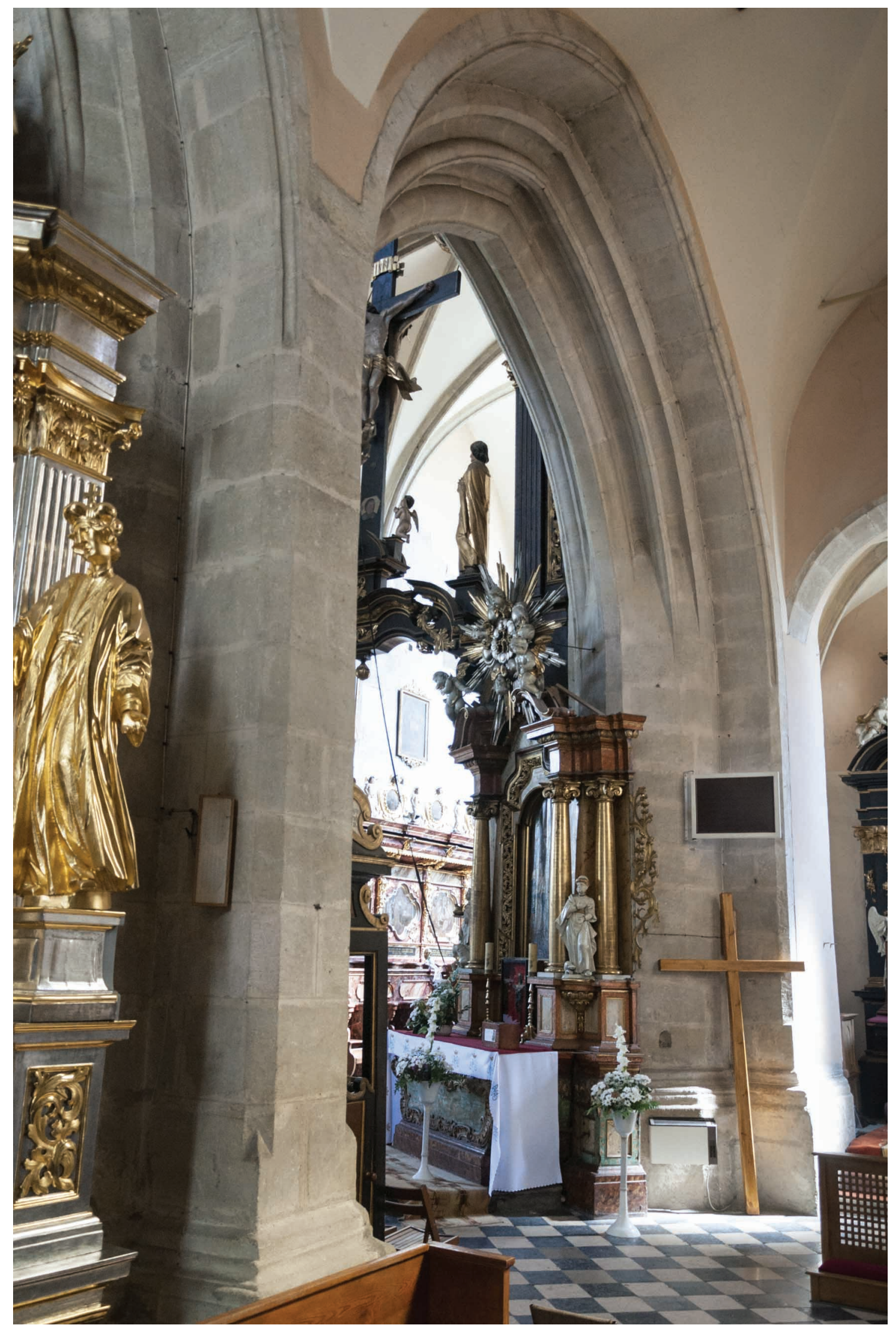

12. Kościót św. Jana Chrzciciela w Skalbmierzu, wnętrze południowej nawy. Fot. Wojciech Sowata 


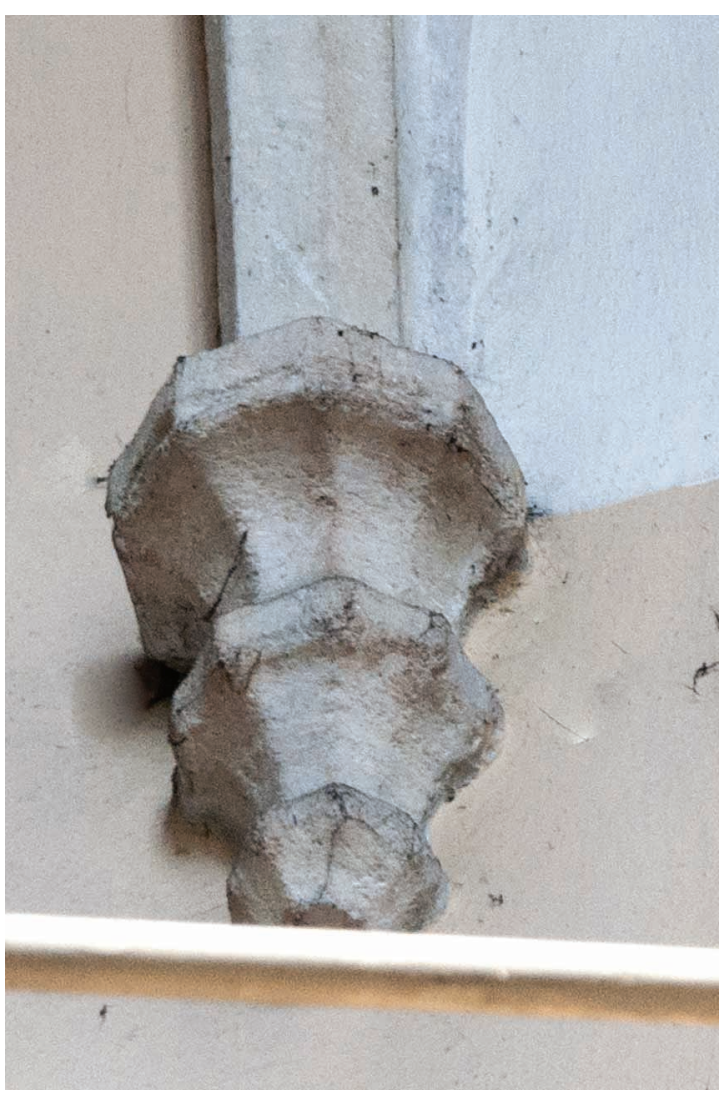

13. Kościót św. Jana Chrzciciela w Skalbmierzu, wspornik sklepienia w prezbiterium. Fot. Wojciech Sowata

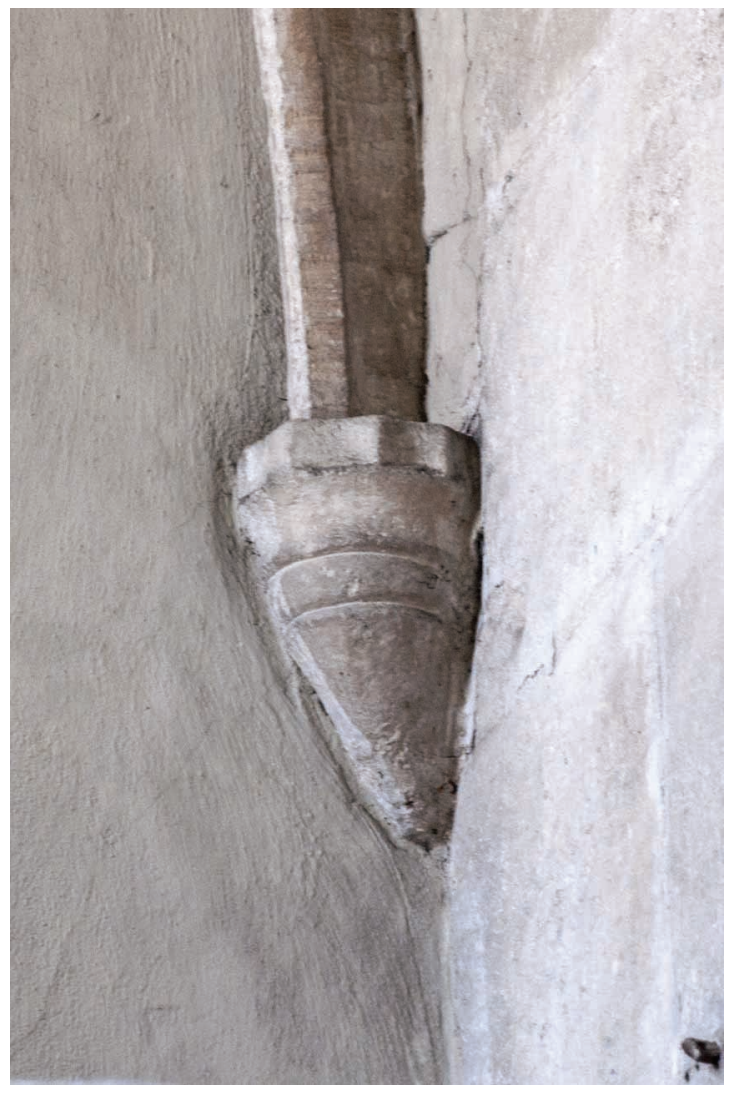

14. Kościót św. Jana Chrzciciela w Skalbmierzu, wspornik sklepienia w zakrystii. Fot. Wojciech Sowała

Analiza wnętrza ujawnia kolejne przesłanki wskazujące na jednolity charakter budowli. Najbardziej widoczne jest to w sposobie adaptacji wieży południowej. Jej wnętrze powiększono, wybierając jedną warstwę ciosów (co widoczne jest w górnych kondygnacjach, ponad sklepieniem) i założono sklepienie krzyżowo-żebrowe. Uzyskane w ten sposób wnętrze połączono arkadami z nawą i prezbiterium. Opasanie jednolitym cokołem arkady tęczowej, półfilara południowo-wschodniego oraz arkady prowadzącej do kaplicy wskazuje na równoczesność prac (il. 12). Dodatkowo motyw ostrosłupa, który dekoruje początek sfazowania krawędzi arkady prowadzącej z kaplicy do prezbiterium, ma swoje analogie w sposobie opracowania podobnej partii profilowania arkad międzynawowych. Kolejnym znaczącym elementem jest pryzmatyczny profil żeber - identyczny w prezbiterium, zakrystii, wieży południowej i wtopionych w ściany nawy żebrach tarczowych. Wprawdzie konsole w prezbiterium różnią się kształtem od zastosowanych w zakrystii, jednak dokładniejszy ogląd ujawnia, że te ostatnie są w istocie uproszczoną lub nie do końca odkutą wersją tych z prezbiterium (il. 13-14). Niezwykle intrygującym elementem jest konsola i fragment służki znajdujący się po południowej stronie arkady tęczowej, za ołtarzem św. Anny (il. 15) ${ }^{41}$. Ma ona ten sam kształt, lecz jest znacznie większa od konsol wspierających żebra w chórze. Na obecnym etapie badań (bez możliwości wglądu za ołtarz i dokładnej analizy reliktów) trudno z całą pewnością stwierdzić, czy są to pozostałości

\footnotetext{
${ }^{41} \mathrm{~W}$ tym miejscu chciałbym bardzo serdecznie podziękować Waldemarowi Glińskiemu za udostępnienie zdjęć i wyników nadzorów archeologicznych prac prowadzonych w kolegiacie.
} 


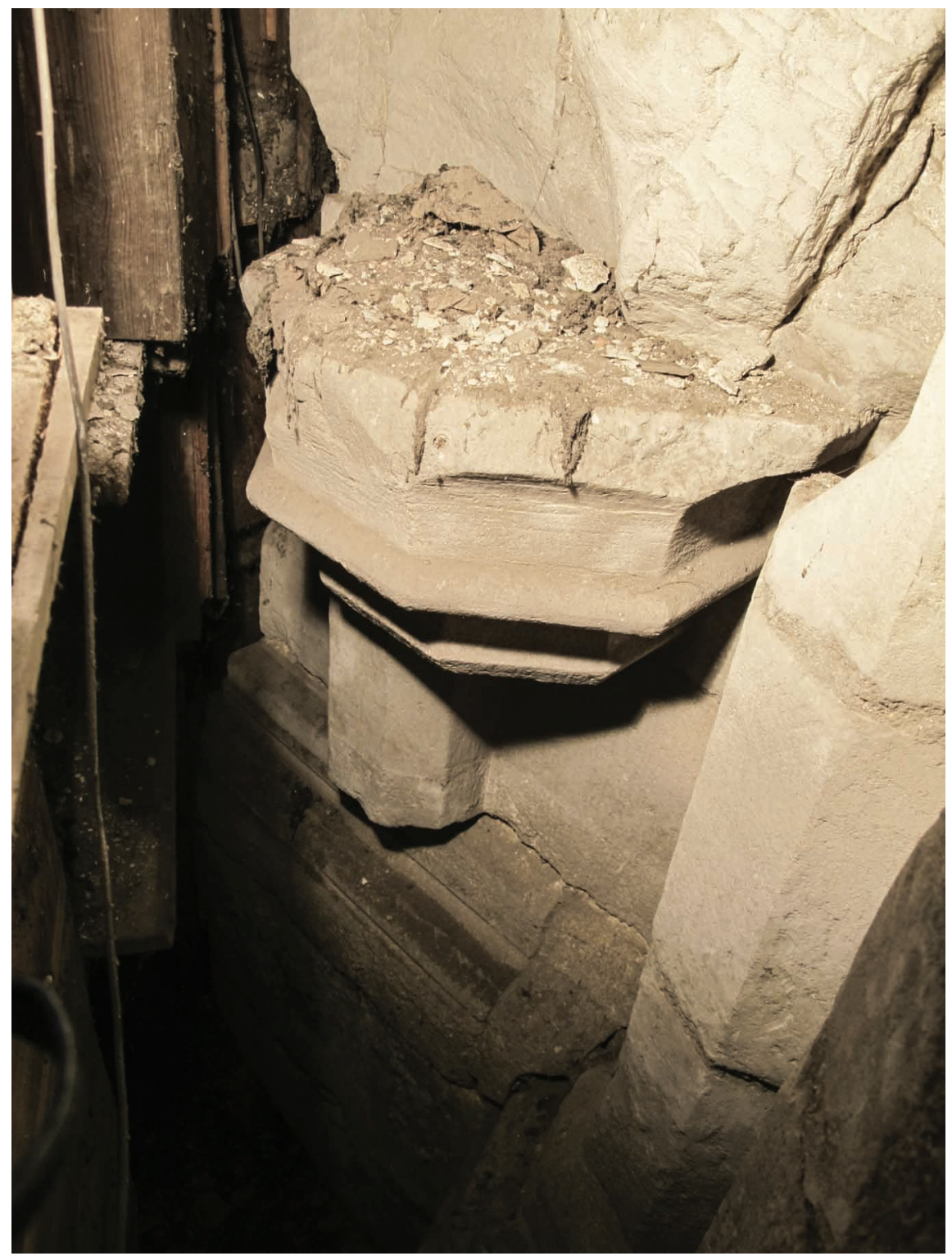

15. Kościót św. Jana Chrzciciela w Skalbmierzu, konsola na arkadzie tęczowej. Fot. Waldemar Gliński

tabernakulum, lektorium, czy podstawa pod rzeźbę. Wydaje się jednak, że pierwsza możliwość jest najbardziej prawdopodobna. Tabernakulum o wieżowym kształcie wraz z towarzyszącym mu ołtarzem notowane jest w wizytacjach z początku XVII w. Na taką interpretację wskazuje także wysokość zawieszenia konsoli (około jednego metra nad posadzką) i pozostałości żelaznego mocowania, wkute w służkę sklepienia na wysokości około czterech metrów (które można interpretować jako element mocujący i stabilizujący hełm wieńczący tabernakulum $)^{42}$. Interesujący jest również fakt, że w tym miejscu profilowanie łuku tęczowego rozpoczyna się znacznie powyżej partii cokołowej, co umożliwiło zamocowanie konsoli i domniemanego tabernakulum do płaszczyzny tęczy - gdyby nie ten zabieg całość musiano by zamontować, z braku miejsca, na profilowaniu. Zatem jest to element pierwotnej koncepcji.

${ }^{42}$ AKMK, AVCap. 28: Acta visitationis exterioris..., k. 351r. 


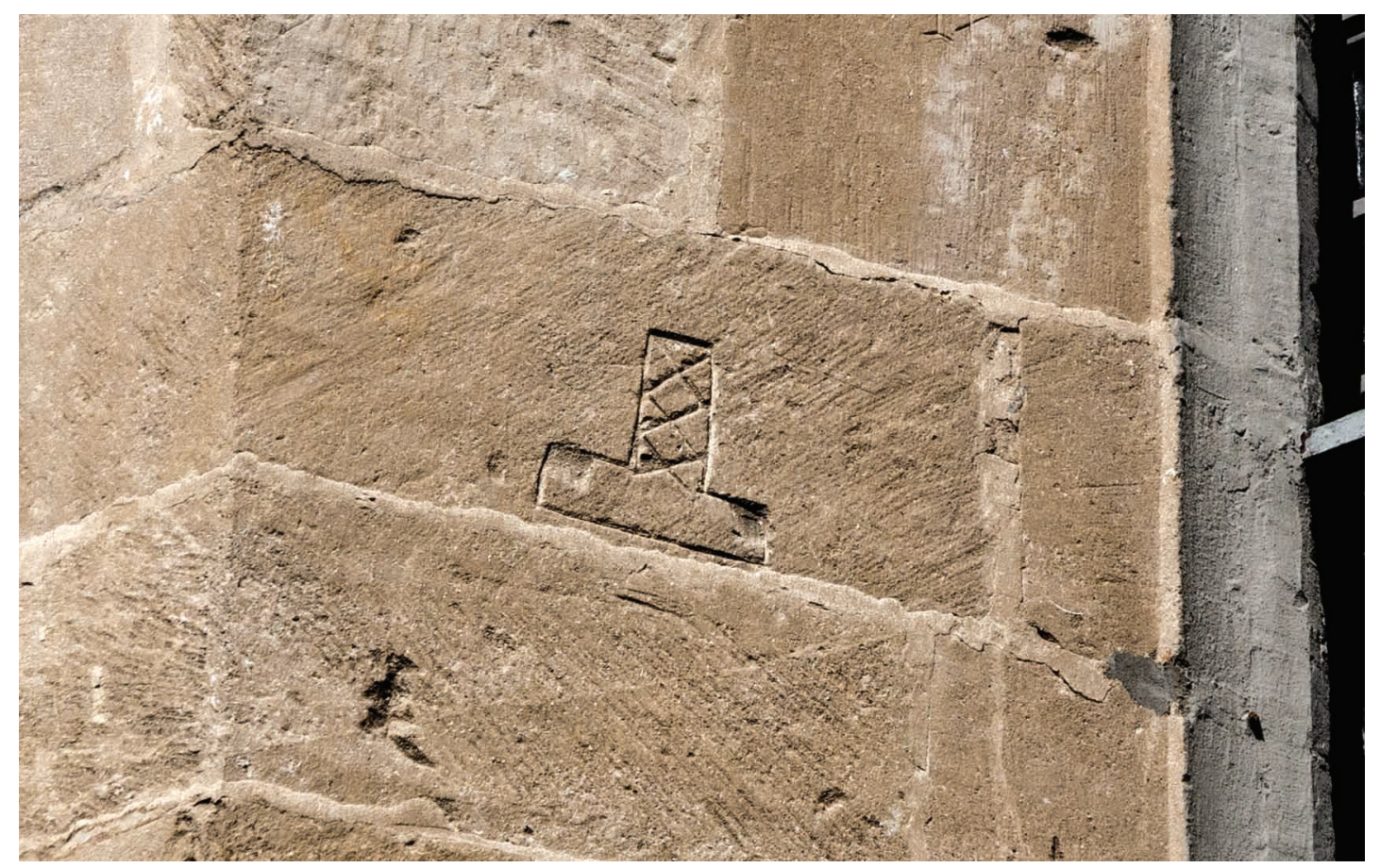

16. Kościót św. Jana Chrzciciela w Skalbmierzu, domniemany plan kościoła. Fot. Wojciech Sowata

W świetle powyższych spostrzeżeń trudno podtrzymać twierdzenie o wykonaniu w pierwszej kolejności korpusu nawowego, a następnie odbudowaniu prezbiterium ${ }^{43}$. Przeczą temu również względy praktyczne - priorytetem przy odbudowie było zapewne jak najszybsze odzyskanie przestrzeni do sprawowania liturgii, a biorąc pod uwagę, że ściany lateralne romańskiego kościoła zachowały się niemal w pełnej wysokości, założyć należy, że to na remoncie tej części skupiono się w pierwszej kolejności. Dodatkową przesłanką może być starannie odkuty na glifie południowo-zachodniego okna prezbiterium schemat, który najprawdopodobniej wyobraża czteroprzęsłowy, zamknięty prostą ścianą od wschodu i wieżami flankującymi fasadę budynek (il. 16) ${ }^{44}$. Jeżeli faktycznie jest to projekt odbudowy, wskazywałby on, że początkowo zamierzano tylko odnowić uszkodzoną świątynię. Natomiast wspomniane elementy - wspólne dla wszystkich części budowli - sugerują, że dość szybko podjęto decyzję o wzniesieniu kościoła w obecnym kształcie.

Być może śladem dokonanej w trakcie budowy zmiany koncepcji są zaburzenia kamiennego wątku na fasadzie. Widoczny symetrycznie po obu stronach osi kościoła brak przewiązania górnych partii ścian zachodnich naw bocznych z główną zdaje się świadczyć o tym, że pierwotnie świątynia miała być niższa. Z kolei brak śladów jakichkolwiek przeróbek na filarach międzynawowych wskazuje, że zmiana miała miejsce we wczesnej fazie wznoszenia budowli.

W dotychczasowej literaturze przyjmuje się, że kościół w obecnej postaci powstał po trzęsieniu ziemi, które nawiedziło Małopolskę w 1443 r. i poważnie uszkodziło świątynię

\footnotetext{
${ }^{43}$ „Skalbmierz”, w: Katalog Zabytków Sztuki w Polsce, s. 83; PencaKowski, WŁodareK, „Skalbmierz”, s. 206.

${ }^{44}$ Przyjęcie takiej interpretacji oznaczałoby też, że ostatecznie zdecydowano się zmienić rzut wschodniego przęła na trapezowy (być może ze względu na uszkodzenia ścian spowodowane trzęsieniem ziemi) oraz przekryć sklepieniami również przestrzeń nawy pomiędzy wieżami. Być może jest to również wskazówka, że empora zachodnia istniała do czasu trzęsienia ziemi.
} 


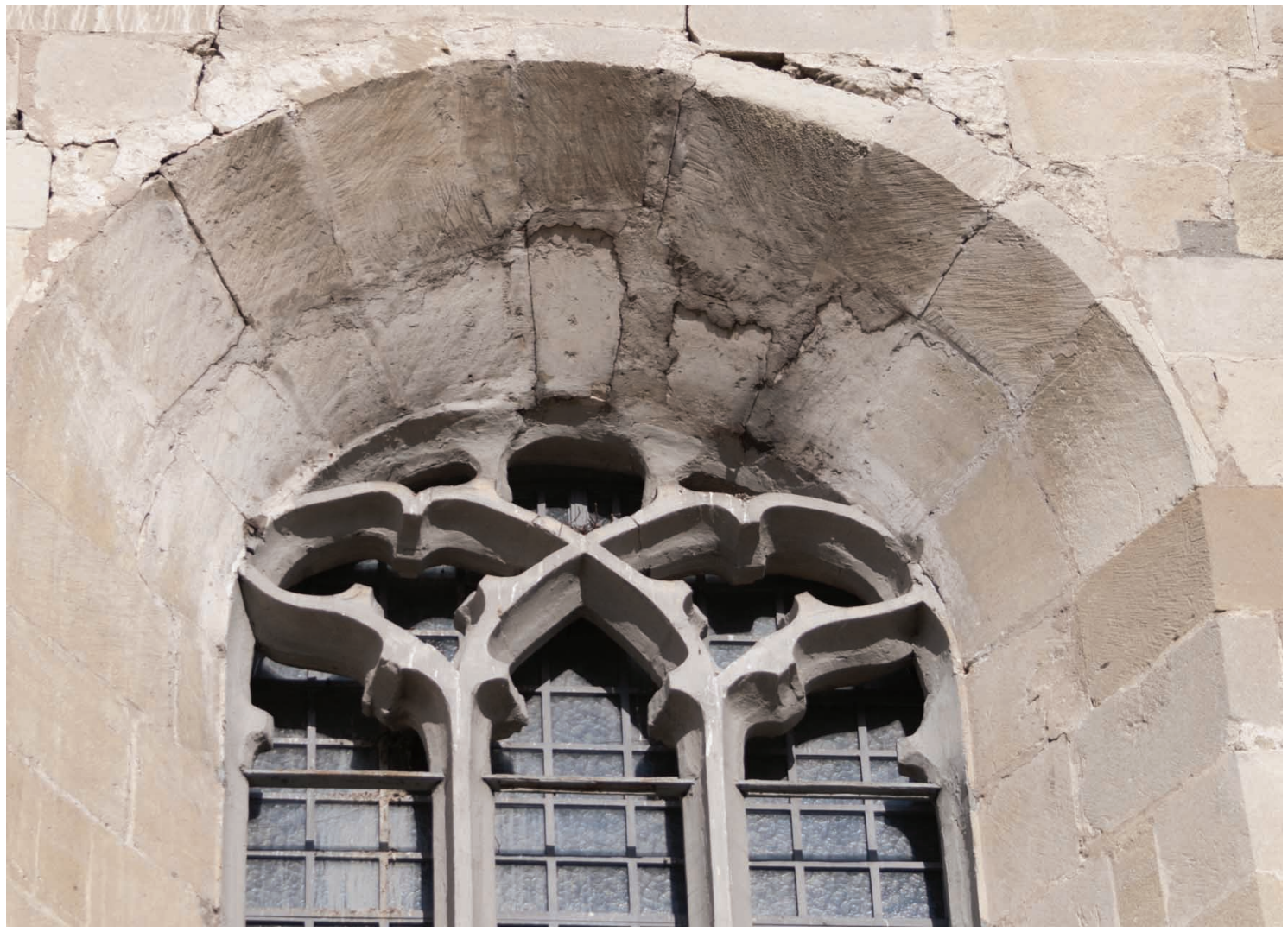

17. Kościót św. Jana Chrzciciela w Skalbmierzu, maswerk w południowo-wschodnim oknie prezbiterium. Fot. Wojciech Sowata

skalbmierską. W istocie taki scenariusz na obecnym etapie badań należy przyjąć jako najbardziej prawdopodobny. Z tego okresu pochodzą też inne wzmianki w dokumentach, mogące wskazywać na prowadzenie prac przy kolegiacie. W 1447 r. pewną sumę pieniędzy ,pro fabrica ecclesia [sic] in scarbimiria” przekazali tamtejsi mieszczanie - Maciej Jaczka wraz z żoną Elżbietą ${ }^{45}$. W 1455 r. Zbigniew Oleśnicki wydał przywilej dla skalbmierskiego bractwa krawców, przyznając sto czterdzieści dni odpustu. Jak zauważyła Maria Koczerska, tak duży odpust przyznawany był tylko w wyjątkowych wypadkach ${ }^{46}$, więc prawdopodobne jest, że został udzielony właśnie za zaangażowanie w budowę kolegiaty. Z wydatkami, jakie mieszczanie musieli ponieść dla odbudowy świątyni, związany jest też zapewne przywilej zwalniający ich z opłat targowych w całym królestwie, udzielony przez Władysława Warneńczyka w 1444 r. dzięki zabiegom Jakuba z Sienna, ówczesnego prepozyta skalbmierskiej kolegiaty ${ }^{47}$. Niezwykle istotny wydaje się odnaleziony przez Bolesława Przybyszewskiego w aktach kapituły katedralnej zapis, mówiący o przeszkleniu kościoła w 1460 r. przez skalbmierskiego mistrza Grzegorza ${ }^{48}$. Na jego podstawie można przypuścić, że przynajmniej ściany lateralne oraz dachy były już wtedy ukończone.

\footnotetext{
${ }^{45}$ Cracovia Artificum: Supplementa, s. 200.

46 Znane są tylko dwa takie przypadki. Zob. Wiktor Szymborski, Odpusty w Polsce średniowiecznej (Kraków: Historia Iagellonica, 2011), s. 437. Zob. też: Maria KoczerskA, Zbigniew Oleśnicki i Kościót krakowski w czasach jego pontyfikatu (1423-1455) (Warszawa: DiG, 2004), s. 105-106, 256-257.

${ }^{47}$ Romanowski, „Dzieje miasta Skalbmierza”, s. 238.

${ }^{48}$ Cracovia Artificum: Supplementa, s. 81.
} 


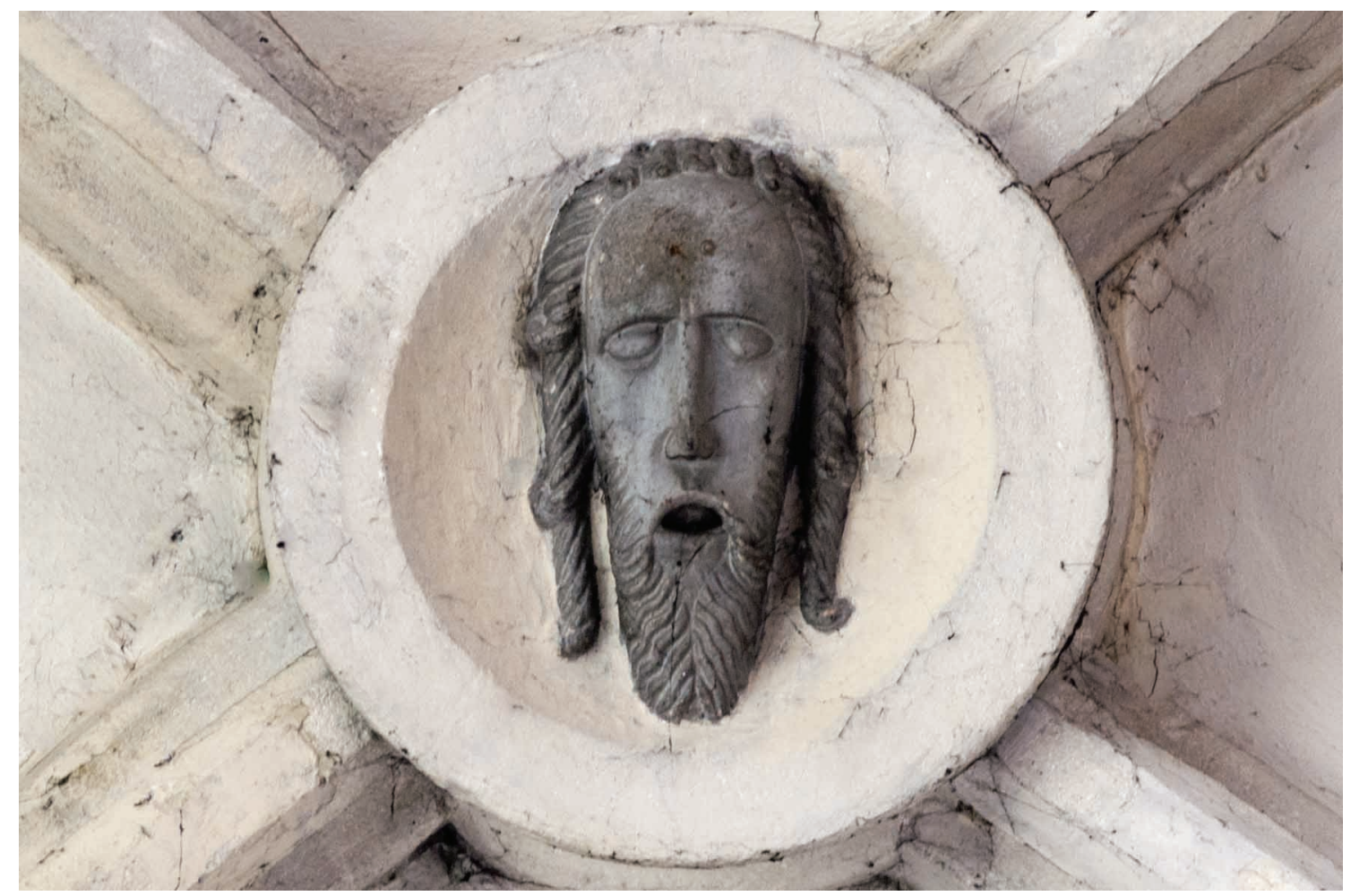

18. Kościót św. Jana Chrzciciela w Skalbmierzu, zwornik z głowq Jana Chrzciciela na misie. Fot. Wojciech Sowata

Przyjęcie takiej chronologii budowy jest możliwe, pomimo datowania maswerku w południowo-wschodnim oknie chóru (podobnie jak pozostałych) na początek XVI stulecia (il. 17) ${ }^{49}$. Dokładna analiza pozwala stwierdzić, że jego szczyt został bardzo silnie przekształcony (prawdopodobnie w latach 70. XIX w.) i, choć być może zawiera fragmenty oryginalnych elementów, są one zmienione w stopniu uniemożliwiającym rekonstrukcję, a co za tym idzie również precyzyjne datowanie. Proste laskowania w pozostałych oknach prezbiterium są zapewne pierwotne, na co wskazuje zarówno stan zachowania, jak i najprawdopodobniej oryginalne szprosy, jednak również tutaj górna partia okien została przerobiona. Maswerki w korpusie nawowym są z pewnością wtórne i również XIX-wieczne, o czym świadczą zdjęcia kościoła, na których brakuje wypełnienia w oknach południowo-zachodnim i północno-wschodnim. Poza tym wykrój górnej partii obramień nie zgadza się z wykrojem okien.

Analiza rzeźby na zwornikach chóru również nie wyklucza takiego datowania. Mitra ma kształt w późnym średniowieczu obiegowy, natomiast głowa Jana Chrzciciela, pomimo silnego wystylizowania, wykazuje cechy często spotykane w rzeźbie małopolskiej w XV w. (il. 18). Wydłużenie twarzy, symetrycznie rozdzielona na dwie części broda, pozlepiane w „kluskowate”, długie pukle włosy, opadające na zewnątrz kąciki oczu, pionowa zmarszczka pomiędzy oczami oraz długi, wąski i prosty nos z niewielkimi płatkami można zestawić z twarzą Chrystusa z krucyfiksów w Opatowie (1420-1425) ${ }^{50}$ czy Szańcu

\footnotetext{
49 Tomasz Węclawowicz, Małgorzata Pietrzykówna, „Maswerki w kościołach Małopolski”, Rocznik Krakowski 55 (1989), s. 72.

${ }^{50}$ Dobrosława Horzela, Późnogotycka rzeźba drewniana w Małopolsce około 1440-1477 (Kraków: Societas Vistulana, 2012), s. 67.
} 


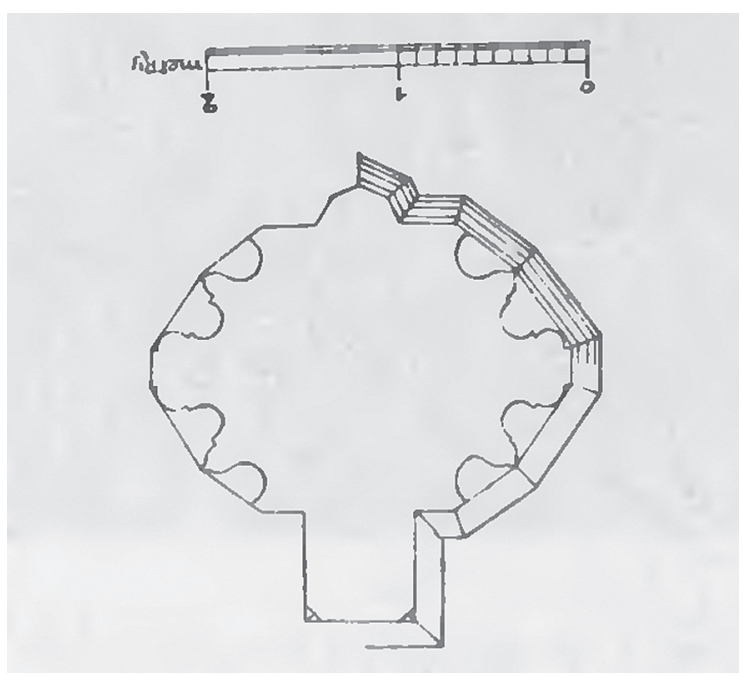

19. Kościót św. Jana Chrzciciela w Skalbmierzu, rzut filaru nawy, rys. Adolf Szyszko-Bohusz. Repr. za: Adolf Szyszko-Bohusz, Beszowa, Skalbmierz i system krakowski, kol. 75, fig. 28

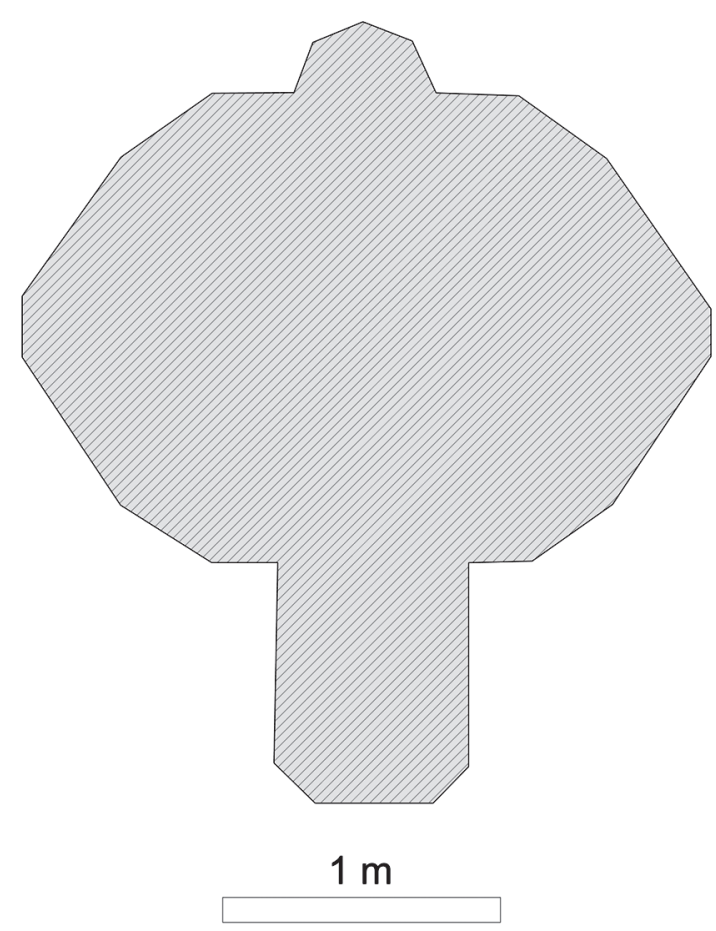

21. Kościół Bożego Ciała w Krakowie, rzut filaru nawy. Rys. Maciej Krzywka

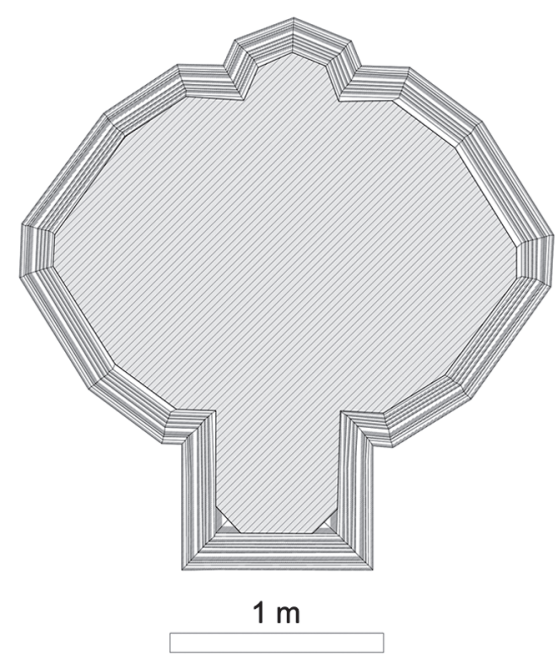

20. Kościót św. Katarzyny w Krakowie, rzut filaru nawy. Rys. Maciej Krzywka

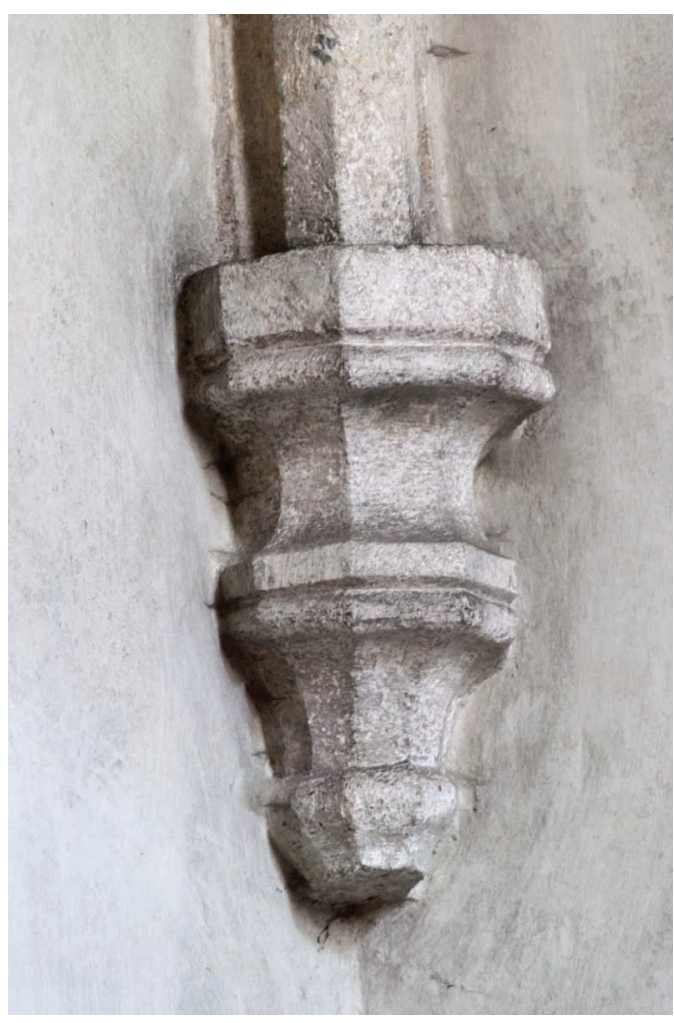

22. Kościót Bożego Ciała w Krakowie, wspornik sklepienia w kaplicy św. Anny. Fot. Wojciech Sowata 


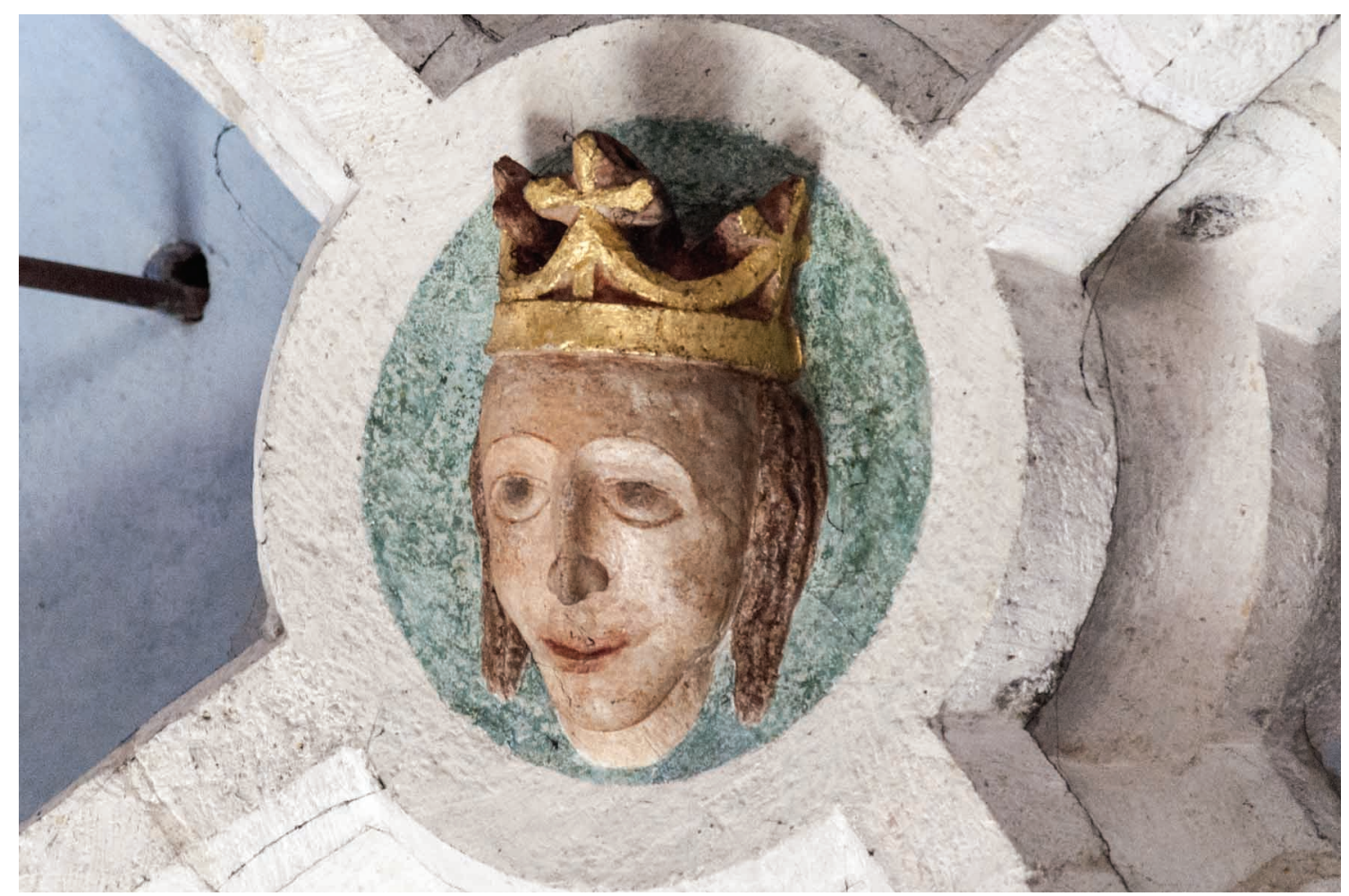

23. Kościót Bożego Ciała w Krakowie, zwornik sklepienia w kaplicy św. Anny. Fot. Wojciech Sowała

(1450-1465) ${ }^{51}$. Motyw włosów skręconych w równoległe pukle nad czołem również pojawia się w połowie wieku w dziełach warsztatu Mistrza Krucyfiksu z Szańca.

W literaturze zwracano już uwagę na zależność architektury skalbmierskiej kolegiaty od XIV-wiecznych krakowskich bazylik. Dokładniejsza analiza wykazuje, że najwięcej cech wspólnych łączy ją z kościołami św. Katarzyny i Bożego Ciała na Kazimierzu. Zestawienie z tym pierwszym ujawnia podobieństwo proporcji elewacji wewnętrznych i przekroju filarów międzynawowych (il. 19-20), jak również sposobu rozrzeźbienia podłuczy arkad międzynawowych, artykulacji pionowej elewacji wewnętrznych nawy za pomocą wtopionej $\mathrm{w}$ ścianę ośmiokątnej służki oraz zastosowania ostrosłupowego motywu do dekoracji podstawy zfazowania krawędzi arkad łączących przypory. Zestawienie z kościołem Bożego Ciała pozwala wskazać jeszcze więcej wspólnych elementów. Takie same są proporcje przypór w stosunku do filarów nawy głównej oraz jej elewacji wewnętrznych, gdzie stosunek wysokości arkad do całkowitej wysokości ściany wynosi 1:1,952. Niemal identyczny jest przekrój filarów (il. 21), sposób opracowania podłuczy arkad (w Skalbmierzu bogatszy jedynie o jeden profil gruszkowy) oraz pionowe podziały elewacji wewnętrznych nawy głównej za pomocą służek o przekroju połowy ośmiokąta. Motyw ostrosłupa, zdobiący nasadę sfazowania arkad łączących przypory, występuje w kościele Bożego Ciała nie tylko na filarach, ale również na arkadzie prowadzącej do kaplicy św. Anny, której żebra sklepienne oraz konsole je podtrzymujące mają bardzo zbliżony do skalbmierskich profil (il. 22). Ponadto głowa kobiety w koronie wyobrażona na zworniku w kaplicy wydaje się również podobna do głowy Jana Chrzciciela w Skalbmierzu. Zwraca

\footnotetext{
${ }^{51}$ Ibid., s. 55-57.

${ }^{52}$ Crossley, Gothic Architecture in the Reign of Kasimir the Great, s. 93.
} 


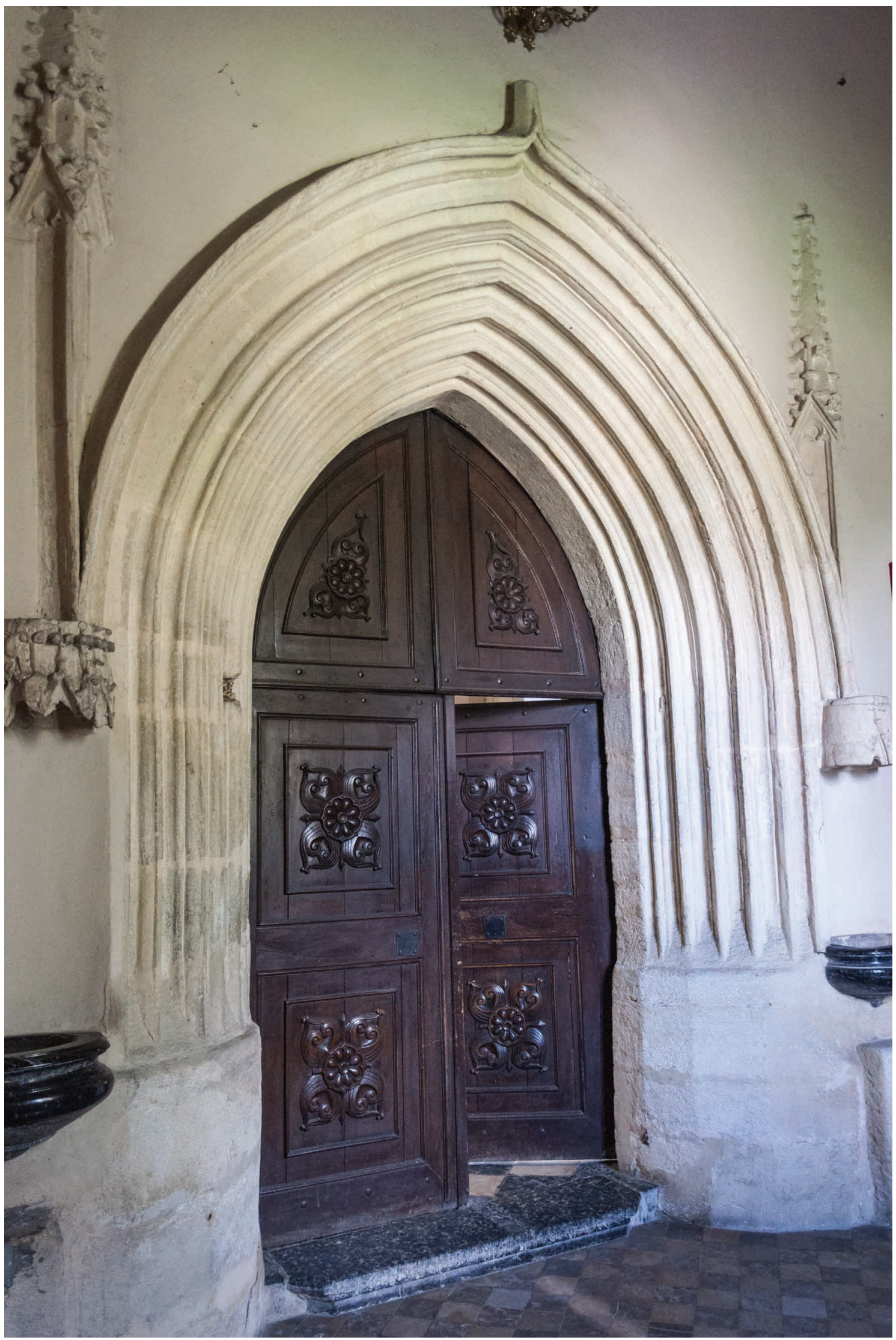

24. Kościót św. Jana Chrzciciela w Skalbmierzu, portal pótnocny. Fot. Wojciech Sowała 
uwagę zwłaszcza długi, wąski i prosty nos z niewielkimi, delikatnymi płatkami oraz opadające zewnętrzne kąciki oczu. Jednak poziom uproszczenia obydwu dzieł uniemożliwia wyciaganie jakichkolwiek dalej idących wniosków (il. 23). Obydwa kościoły łączy też identyczna kompozycja portali północnych, z tym że profilowanie ościeży w Skalbmierzu powtarza analogiczny element z południowego portalu kazimierskiej fary (il. 24).

Elementem, który nie pozwala uznać skalbmierskiej kolegiaty za uproszczoną kopię kościoła Bożego Ciała, jest brak gzymsu powyżej arkad nawy głównej oraz wnęki podokiennej rozbijającej powierzchnię ściany nad wspomnianym gzymsem. Taka kompozycja elewacji wewnętrznych zbliża omawianą świątynię do kościoła św. Elżbiety we Wrocławiu. Jak zauważył Jakub Adamski, sposób artykulacji wnętrza wrocławskiej fary był chętnie powtarzany do schyłku XV stulecia w licznych śląskich kościołach ${ }^{53}$. Wskazać tu można dla przykładu fary w Dzierżoniowie (koniec 1. ćwierci XV w.) ${ }^{54}$, Jeleniej Górze (przełom 2. i 3. ćwierci XV w.) ${ }^{55}$, Chojnowie (założenie sklepień w 1468 r.) ${ }^{56}$, czy Oleśnicy (sklepienia w 1469 r.) ${ }^{57}$. Również zastosowanie zwornika w żebrze jarzmowym wydaje się łączyć kościół skalbmierski ze Śląskiem. Podobny motyw występuje w wielu tamtejszych kościołach na czele z katedrą (w nawach bocznych), kolegiatą Świętego Krzyża (w prezbiterium) i kościołem Bożego Ciała we Wrocławiu (w nawie głównej), czy farach w Strzegomiu (w nawach bocznych) i Namysłowie (w nawie głównej).

Powyższe uwagi - prowadzące do wniosku, że muratorzy, którzy pracowali przy kolegiacie św. Jana Chrzciciela w Skalbmierzu znali bardzo dobrze architekturę kościołów Bożego Ciała i św. Katarzyny na Kazimierzu oraz że nieobca im była tradycja budowlana Śląska - nie stanowią niestety podstawy do jednoznacznego datowania obiektu. Kazimierska fara wznoszona była zapewne od lat 40. XIV w. Jak ustalił Węcławowicz, w 1405 r. gotowe było prezbiterium i nawy boczne, natomiast nie jest jasne, kiedy ukończono ściany nawy głównej ${ }^{58}$. Nie wiadomo również, kiedy dokładnie wystawiono kaplicę św. Anny - autorzy Katalogu Zabytków Sztuki w Polsce określają ją jako powstałą „zapewne w drugiej połowie XV wieku"59. Niewiele też daje w tym zakresie odniesienie się do kościoła św. Katarzyny, który co prawda był tematem licznych studiów, jednak fazy budowy jego korpusu nawowego w dalszym ciągu nie są wystarczająco rozpoznane. W chwili obecnej uważa się, że czas jego budowy przypadał na okres od lat 70. XIV do początku XVI w. ${ }^{60} \mathrm{Na}$ obecnym etapie badań należy zatem przyjąć wynikające ze źródeł pisanych daty 1443-1460 jako czas budowy skalbmierskiego kościoła.

\footnotetext{
53 Jakub ADAmSKI, Gotycka architektura sakralna na Ślqsku w latach 1200-1420. Główne kierunki rozwoju (Kraków: Societas Vistulana, 2017), s. 411.

${ }^{54}$ Ibid., s. 578.

55 Ibid., s. 555.

${ }^{56}$ Ibid., s. 570 .

${ }^{57}$ Ibid., s. 575.

${ }^{58}$ Tomasz WęCŁawowicz, Cocto latere nobilitavit. O ceglanych murach kościołów średniowiecznego Krakowa (Kraków: Krakowskie Towarzystwo Edukacyjne - Oficyna Wydawnicza AFM, 2013), s. 171-174. Dodatkowe zamieszanie wprowadza sam Autor, datując na stronie 174 nawę główną na 2. ćwierć XV w., by pięć stron dalej stwierdzić, że powstała ona w ostatniej tercji tego stulecia.

${ }^{59}$ Franciszek SтоLот et al., ,Kościół par. p. w. Bożego Ciała, klasztor kanoników regularnych laterańskich i zabudowania poklasztorne", w: Katalog Zabytków Sztuki w Polsce, red. Jerzy Z. Lozí́ski, Barbara WolfF-ŁozińsKA, t. 4: Miasto Kraków, red. Izabela Rejduch-Samkowa, Jan SAmeK, cz. 4/1: Kazimierz i Stradom - kościoby i klasztory, oprac. Ewa CHOJECKA et al. (Warszawa: WAiF, 1987), s. 50.

${ }^{60}$ Literaturę zestawił ostatnio Jakub Adamski. Zob. Jakub ADAMSKI, „O genetycznej i chronologicznej zależności portali augustiańskiego kościoła św. Katarzyny na Kazimierzu w Krakowie i fary św. Elżbiety w Koszycach”, Folia Historiae Artium. Seria nowa 16 (2018), s. 35-61.
} 


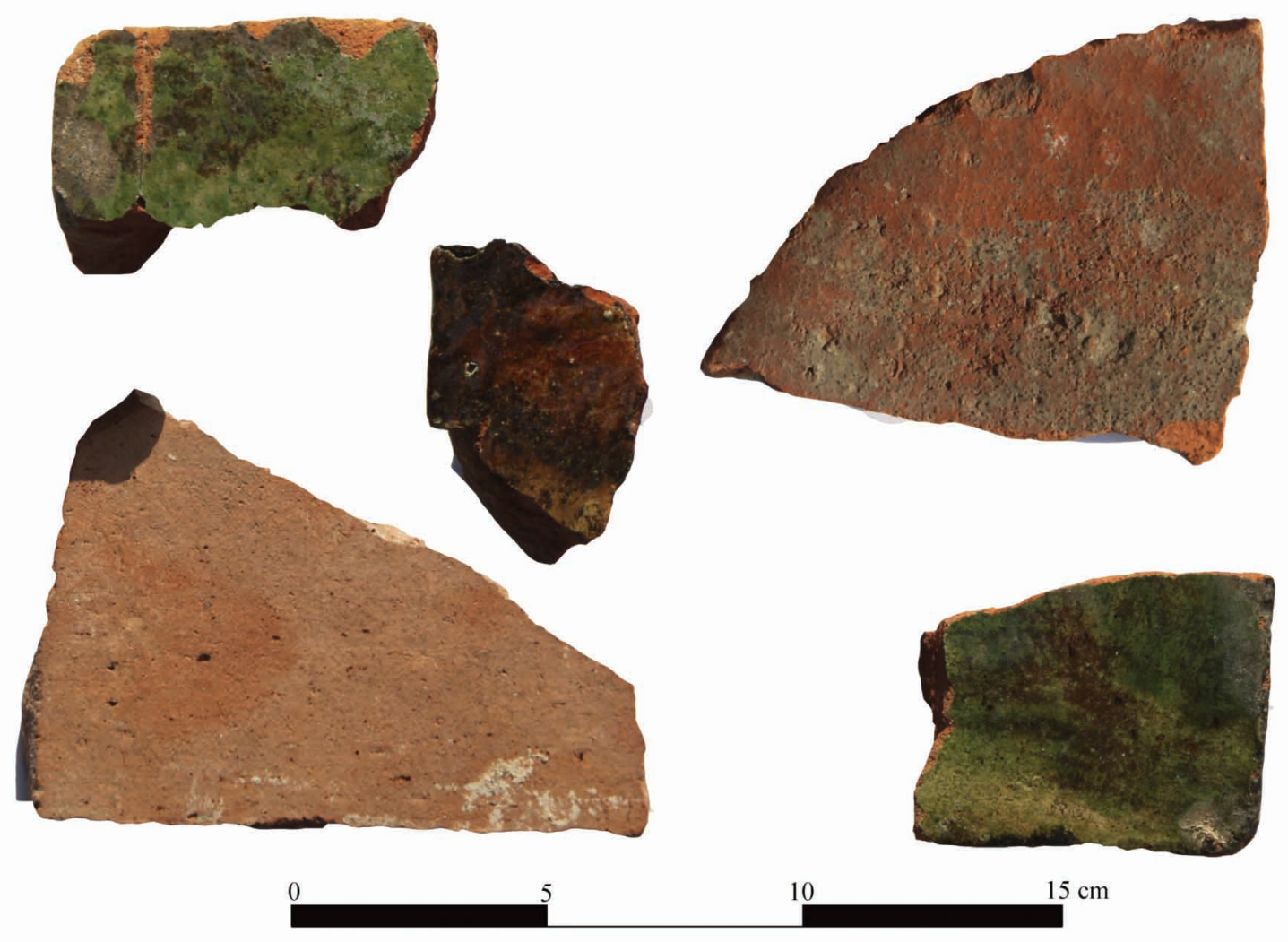

25. Kościót św. Jana Chrzciciela w Skalbmierzu, płytki posadzkowe. Fot. Waldemar Gliński

W wyniku omówionych prac budowlanych kolegiata skalbmierska uzyskała niezwykle ciekawą i nośną ideowo formę. Połączono w niej najmodniejszy w stolicy diecezji model bazyliki z długim chórem z doskonale widocznymi w bryle reliktami starszego kościoła. Zarówno dla przybywających do Skalbmierza szlakiem z Krakowa, jak i idących od strony rynku, doskonale widoczne na styku prezbiterium i nawy romańskie wieże (z zachowanymi w górnej kondygnacji biforiami) stanowiły dominantę w sylwetce kościoła. Choć świątynia powstała ze składek wiernych ${ }^{61}$, trudno sobie wyobrazić, aby fabryką kierował ktoś inny niż skalbmierscy kanonicy. Jeśli przyjąć sugerowane w niniejszym artykule daty budowy, to najważniejsze decyzje dotyczące formy kościoła oraz wyboru warsztatu musiały zapaść za prepozytury Jakuba z Sienna (1442-1456). Obejmując probostwo skalbmierskie, późniejszy arcybiskup gnieźnieński (urodzony w 1413 r.) miał już za sobą studia teologiczne w Rzymie, kanonikat w katedrze krakowskiej i działalność w kancelarii królewskiej. W 1444 r., w uznaniu zasług objął również prepozyturę katedralną. Dzięki zaletom charakteru cieszył się już wtedy zaufaniem zarówno króla, jak i biskupa krakowskiego $^{62}$. Nie może zatem dziwić, że znakomicie wykształcony Sienieński potrafił wykorzystać relikty starszego kościoła do podkreślenia szacownej metryki kolegiaty, a tym samym podniesienia jej prestiżu. Takie postępowanie wpisywałoby się znakomicie w schemat działań o podobnym podłożu ideowym, podejmowanych zarówno w Rzymie, jak i w Krakowie (zachowane na Wawelu: rotunda Najświętszej Marii Panny, kaplica św.

\footnotetext{
${ }^{61}$ DŁugosz, Liber beneficiorum dioecesis Cracoviensis, s. 516.

${ }^{62}$ Feliks KirYK, „Jakub z Sienna”, w: Polski stownik biograficzny, t. 10, red. Kazimierz LePszy et al. (Wrocław: Ossolineum, 1962-1964), s. 364-367.
} 


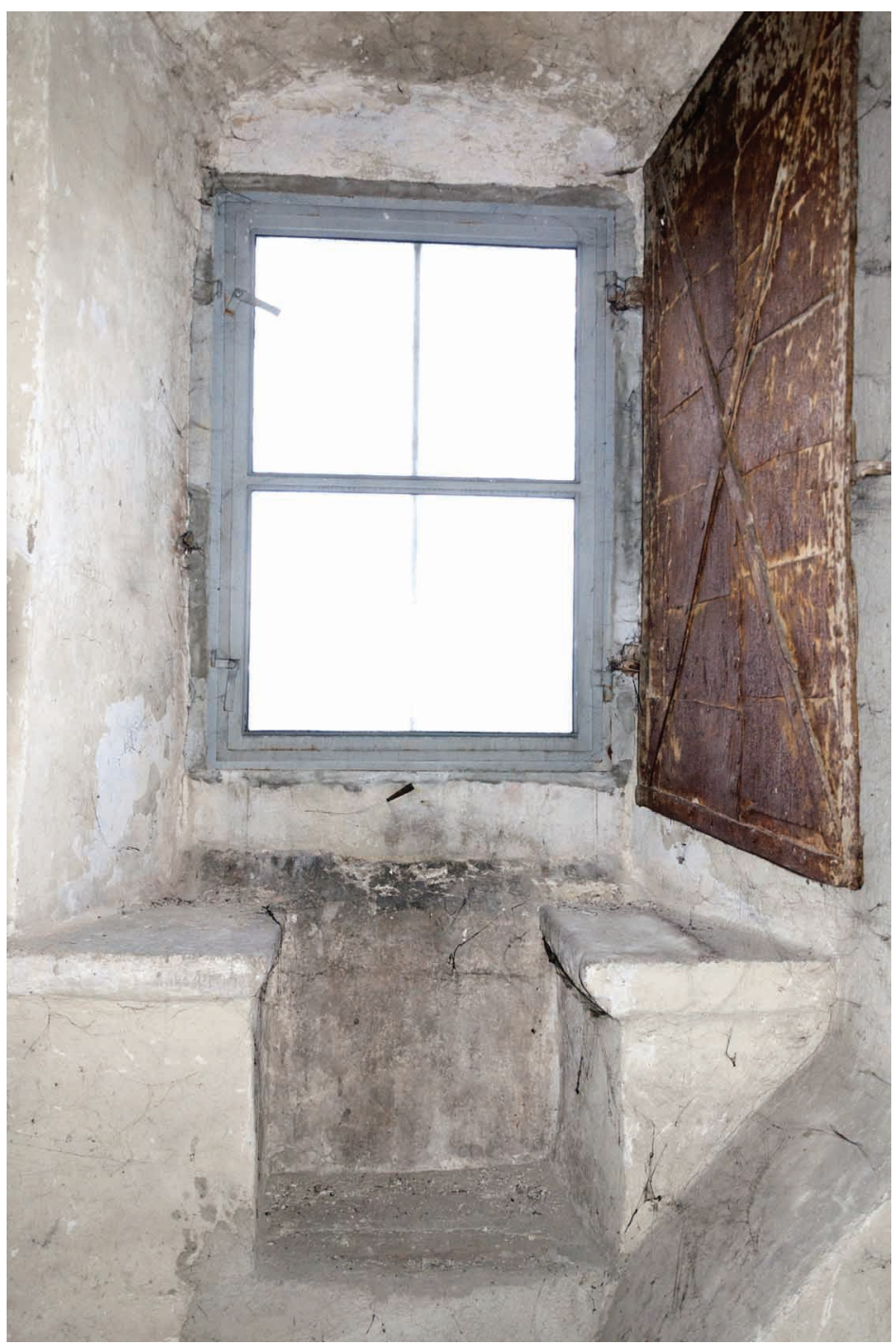

\author{
26. Kościót św. Jana \\ Chrzciciela w Skalbmierzu, \\ kapitularz. \\ Fot. Wojciech Sowata
}

Marii Egipcjanki i zachodnie wieże katedry - wynik „polityki historycznej” Kazimierza Wielkiego) ${ }^{63}$.

Kolejnym elementem, w którego kształtowaniu znaczenie miał zapewne przekaz ideowy, jest północna, skierowana na miasto elewacja kolegiaty. To właśnie od tej strony przewidziano główne, dekoracyjnie opracowane wejście do kościoła (portal zachodni nie zachował się, jednak brak śladów przekuć na fasadzie świadczy o tym, że miał on formę znacznie skromniejsza, bez fial, konsol czy baldachimów). Poza wspomnianymi wieżami zadbano też o wyróżnienie części przeznaczonej dla kanoników. Osiagnięto to dzięki zastosowaniu okien o prostokątnym wykroju, z których to znajdujące się w kapitularzu

\footnotetext{
${ }^{63}$ Marek WaLCZAK, „Dlaczego król Kazimierz Wielki zachował od zniszczenia wawelską rotundę Najświętszej Marii Panny", w: Lapides viventes. Zaginiony Kraków wieków średnich. Księga dedykowana profesor Klementynie Żurowskiej, red. Jerzy Gadomski (Kraków: Wydawnictwo UJ, 2005), s. 93-114; Piotr PaJor, „Relikty romańskie w murach gotyckiej katedry na Wawelu. Przyczynek do badań nad programem historycznym w fundacjach artystycznych Kazimierza Wielkiego", w: Procesy przemian w sztuce średniowiecznej. Przełom - regres - innowacja - tradycja. Studia z historii sztuki, red. Rafał Eysymontт, Romuald KaczmareK (Warszawa: Stowarzyszenie Historyków Sztuki, 2014), s. 105-116; ID., „Król spogląda w przeszłość. Romańskie relikty w murach katedry krakowskiej i kolegiaty w Wiślicy jako nośnik programu historycznego w działalności fundacyjnej Kazimierza Wielkiego", w: Historyzm - tradycja archaizacja. Studia z dziejów świadomości historycznej w średniowieczu i okresie nowożytnym, red. Marek WALCZAK (Kraków: Societas Vistulana, 2015), s. 83-109.
} 
zaopatrzone zostało dodatkowo w dekoracyjnie opracowany parapet. Choć nie jest jasne, jak pierwotnie wyglądała górna część wieżyczki kryjącej klatkę schodową (zaburzenia wątku w tej części zdradzają poważne przeróbki), wieńczący ją obecnie skuty gzyms wskazuje, że miała ona znacznie bardziej reprezentacyjną formę.

Warto również zwrócić uwagę na przemyślane rozwiązania funkcjonalne. Zakładając, że w arkadzie tęczowej znajdowało się lektorium (co w kolegiacie jest wysoce prawdopodobne), przy którym umieszczono sakrarium i ołtarz ${ }^{64}$, przebicie arkad pomiędzy wieżą południową a nawą boczną i chórem zapewniało wygodny ciąg komunikacyjny, pozwalający dyskretnie wejść do prezbiterium bez zakłócania obrzędów. Z XV w. pochodzą też zapewne, znalezione w $2018 \mathrm{r}$. podczas remontu, fragmenty glazurowanych płytek, którymi wyłożono posadzkę przynajmniej w części kościoła (il. 25) ${ }^{65}$. Z kolei rozwiązania zastosowane w budynku zakrystyjnym zdradzają troskę kanoników zarówno o wygodę, jak i właściwe zabezpieczenie kosztowności i dokumentów kapituły. Bezpośrednio za portalem, w północnej ścianie prezbiterium zlokalizowana jest obszerna, dobrze oświetlona, ogrzewana kominkiem zakrystia wikariuszy (z zachowaną gotycką mensą). W jej ścianie zachodniej znajduje się przejście do zakrystii kapitulnej, zabezpieczone ciężkimi, okutymi blachą drzwiami z zamkiem i wmurowanym w ścianę ryglem (zapewne pierwotnym). $\mathrm{Z}$ tego pomieszczenia można się było dostać do sklepionego kolebkowo i również zabezpieczonego pancernymi drzwiami przyziemia wieży północnej (pełniącego rolę skarbca) lub kręconymi schodami wyjść na piętro, gdzie znajdował się kapitularz. Choć jego sklepienie zostało przebudowane w XVII w., zachowały się oryginalne podokienne sedilia oraz krata i być może żelazna okiennica (il. 26). Troska o jak najlepsze zabezpieczenie tej części kościoła mogła też być powodem, dla którego budynek wzniesiono z cegły, materiału bardziej odpornego na temperaturę niż piaskowiec czy wapień. O tym, że ogień był jednym z poważniejszych zagrożeń, jakie brano pod uwagę, świadczy posadzka zachowana w kapitularzu. Wykonano ją z mieszaniny gliny i kruszonej cegły, co zapewnić miało ochronę przeciwpożarową ${ }^{66}$.

Podsumowując, trzeba stwierdzić, że kolegiata św. Jana Chrzciciela w Skalbmierzu jest obiektem, który przy uważnej analizie jawi się jako niezwykle ciekawy przykład oddziaływania zarówno sztuki, jak i kultury Krakowa. Budowla dotychczas marginalizowana w badaniach architektury małopolskiej XV w. zwraca uwagę precyzyjnie wykonaną, wysokiej klasy kamieniarką arkad międzynawowych oraz złożonym i ściśle przemyślanym programem ideowym i funkcjonalnym. Wbrew ustaleniom znanym z literatury przedmiotu, na obecnym etapie badań należy przyjąć, że powstała jako jednolite założenie z wykorzystaniem starszych murów, pomiędzy 1443 a 1460 r., pod patronatem kanoników skalbmierskich, w szczególności Jakuba z Sienna. Jej złożony program ideowy wskazuje, że dla kapituły bardziej istotne okazało się zamanifestowanie łączności ze stolicą oraz podkreślenie metryki instytucji niż pogoń za nowinkami, co może też okazać się kluczem do analizy innych, dotychczas niedocenianych fundacji z tego czasu.

\footnotetext{
${ }^{64}$ Wzmiankowane w źródłach dopiero na początku XVII w., ale zgodne z dość powszechnym w średniowieczu zwyczajem umieszczania ołtarza przy lektorium Zob. Jacqueline Jung, The Gothic Screen: Space, Sculpture, and Community in the Cathedrals of France and Germany ca.1200-1400 (New York: Cambridge University Press, 2013), s. 17-43.

${ }^{65}$ Za konsultację datowania dzięuję dr. hab. Dariuszowi Niemcowi.

${ }^{66}$ Podobna, wykonana z czystej gliny posadzka zachowała się w pomieszczeniach archiwum w katedrze w Spiskiej Kapitule. Zob. Magdaléna JANOvSKÁ, „Architektonické tvaroslovie”, w: Katedrála sv. Martina v Spišskej Kapitule, red. Magdaléna JanovsKá, Vladimír Olejník (Spišské Podhradie: Rímskokatolícka cirkev Biskupstvo Spišské Podhradie 2017), s. 245.
} 


\section{Mediaeval Architecture of the Church of St John the Baptist in Skalbmierz}

The Collegiate Church of St John the Baptist in Skalbmierz is one of the oldest and most important Chapters in the Cracow Diocese. Its beginnings date back to the 1120s. This is the dating of the first Skalbmierz church, subsequently altered in the $15^{\text {th }}$ century. Although researchers paid attention to it already in the $19^{\text {th }}$ century, the first analysis was conducted only in 1913 by Stanisław Tomkowicz and Adolf Szyszko-Bohusz. Further findings are attributed to Andrzej Tomaszewski, author of the reconstruction of the Romanesque look of the church, and to Paweł Pencakowski and Andrzej Włodarek who distinguished three phases in the remodelling lasting from the mid- $15^{\text {th }}$ to the early $16^{\text {th }}$ century.

In the first part of the paper the form of the $12^{\text {th }}$ century church is analysed. The western section traceable in the walls of today's structure seems to have been reconstructed correctly by earlier researchers. However, the reconstruction of the eastern part recreated by Andrzej Tomaszewski as a semi-circular apse raises doubts. The latter stemming first of all from the discovery of a stone sarcophagus placed on the Church's axis just beyond the eastern wall of today's chancel (and beyond the wall outline proposed by Tomaszewski) made in the course of test pit excavations. The sarcophagus was carefully hewn out of a single piece of limestone, which makes it a unique find. Its form and execution methods echo the sarcophagi serving to bury members of the Salian Dynasty in Speyer or Vratislaus II in the Church of SS Peter and Paul at Prague's Vyšehrad. It therefore seems that verification of the to-date reconstruction of the eastern wall of the Skalbmierz church through archaeological research is needed, since it seems highly unlikely for such a sumptuous burial to have been placed outside the church.

The second section of the paper is focused on the church's remodelling conducted in the $15^{\text {th }}$ century.
Based on the analysis of written sources and the investigation of the church's wall, the thesis of a very swift completion of the works has been put forth. The works may have begun promptly after the 1443 earthquake which caused a part of the walls and the ceiling collapse. The year 1460 , marked by the note about the glazing of the church windows, is taken as the date marking the completion of the majority of the works. The comparison of formal solutions and architectural details led to the conclusions that the stonemasons working on the Collegiate Church were very well acquainted with the architecture of the Cracow Church of Corpus Christi. This can be judged in the proportions and structural system of constructing the nave and the aisles. It is also the profiling of the nave arcades and the architectural decoration that closely echo the analogical elements in the Cracow church. In turn, the manner of composing internal elevations, deprived of horizontal articulation and pierced with small windows suggest that also Silesian models were followed. The Skalbmierz church stands out with a meticulous selection of architectural forms that combine the style mode most fashionable in the Diocese capital with simultaneous exposure of the walls of the old building. Such juxtaposition in which architecture was consciously applied to raise the institution's prestige demonstrates the attention with which the Chapter ran the church's fabrica. This should not to be found surprising bearing in mind that it was Jakub of Sienno who was the Chapter's Provost at the time: one of the most enlightened dignitaries at the court and hierarchs of the Polish Church. When in Cracow, Sienieński had many opportunities to view similarly arranged buildings: the Cracow Cathedral or the Chapel of Mary of Egypt at the Wawel Hill.

All the above elements make the Skalbmierz Collegiate Church one of the most interesting $15^{\text {th }}$ century construction projects in Lesser Poland. 


\section{Bibliografia:}

Adamski, Jakub. “O genetycznej i chronologicznej zależności portali augustiańskiego kościoła św. Katarzyny na Kazimierzu w Krakowie i fary św. Elżbiety w Koszycach.” Folia Historiae Artium. Seria nowa 16 (2018): 35-61.

Adamski, Jakub. Gotycka architektura sakralna na Ślasku w latach 1200-1420. Gtówne kierunki rozwoju. Kraków: Societas Vistulana, 2017.

Crossley, Paul. Gothic Architecture in the Reign of Kasimir the Great: Church Architecture in Lesser Poland 1320-1380. Kraków: Ministerstwo Kultury i Sztuki, Zarząd Muzeów i Ochrony Zabytków, 1985.

Dąbrowska, Elżbieta. Studia nad osadnictwem wczesnośredniowiecznym Ziemi Wiślickiej. Wrocław: Ossolineum, 1965.

Ehlers, Caspar. "Die Salischen Kaisergräber im Speyerer Dom.” W Die Salier: Macht im Wandel: Essays, redakcja Laura Heeg, 203-209. München: Minerva, 2011.

Graczyńska, Marta, i Monika Kamińska. "Reqiuescat in pace. Uprzywilejowane miejsca pochówku w architekturze środkowoeuropejskiej w X-XI wieku. Studium przypadku." W Architektura w poczatkach państw Europy Środkowej, redakcja Tomasz Janiak, Dariusz Stryniak, 325-362. Gniezno: Muzeum Początków Państwa Polskiego, 2018.

Gryglewski, Piotr. De Sacra Antiquitate. Odwołania do przeszłości w polskiej architekturze sakralnej XVI wieku. Warszawa: Neriton, 2012.

Grzybkowski, Andrzej. Gotycka architektura murowana w Polsce. Warszawa: Wydawnictwo UW, 2014.

Hanuš, Martin, David Kušnirák, i Michal Slivka. "Výsledky geofizikálneho výskumu zaniknutého benediktínskeho kláštora v Rimavských Janovciach.” Archeologia Historica 42, nr 2 (2017): 651667. DOI:10.5817/AH2017-2-13

Horzela, Dobrosława. Późnogotycka rzeźba drewniana w Małopolsce około 1440-1477. Kraków: Societas Vistulana, 2012.

Janovská, Magdaléna. “Architektonické tvaroslovie.” W Katedrála sv. Martina v Spišskej Kapitule, redakcja Magdaléna Janovská, Vladimír Olejník, 177-245. Spišské Podhradie: Rímskokatolícka cirkev Biskupstvo Spišské Podhradie, 2017.

Jung, Jacqueline. The Gothic Screen: Space, Sculpture, and Community in the Cathedrals of France and Germany ca.1200-1400. New York: Cambridge University Press, 2013.

Koczerska, Maria. Zbigniew Oleśnicki i Kościót krakowski w czasach jego pontyfikatu (14231455). Warszawa: DiG, 2004.

Franciszek Stolot et al. "Kościół par. p. w. Bożego Ciała, klasztor kanoników regularnych laterańskich i zabudowania poklasztorne." W Kazimierz i Stradom - kościoły i klasztory, opracowanie Ewa Chojecka et al., 50. Warszawa: WAiF, 1987. 
Kubica, Ewa. "Katalog zabytków wczesnośredniowiecznej architektury monumentalnej Małopolski, Rusi Halickiej i Wołynia." Materiaty i Sprawozdania Rzeszowskiego Ośrodka Archeologicznego 17 (1996): 164-165.

Kumor, Bolesław Stanisław. Dzieje diecezji krakowskiej do roku 1795, t. 3. Kraków: Wydawnictwo Świętego Stanisława BM, 2000.

Olczak, Stanisław K., i Daniel Olszewski. Parafia Skalbmierz. Zarys dziejów. Kielce: Jedność, 2000.

Pajor, Piotr. "Król spogląda w przeszłość. Romańskie relikty w murach katedry krakowskiej i kolegiaty w Wiślicy jako nośnik programu historycznego w działalności fundacyjnej Kazimierza Wielkiego." W Historyzm - tradycja - archaizacja. Studia z dziejów świadomości historycznej w średniowieczu i okresie nowożytnym, redakcja Marek Walczak, 83-109. Kraków: Societas Vistulana, 2015.

Pajor, Piotr. "Relikty romańskie w murach gotyckiej katedry na Wawelu. Przyczynek do badań nad programem historycznym w fundacjach artystycznych Kazimierza Wielkiego." W Procesy przemian w sztuce średniowiecznej. Przełom - regres - innowacja - tradycja. Studia z historii sztuki, redakcja Rafał Eysymontt, Romuald Kaczmarek, 105-116. Warszawa: SHS, 2014.

Pencakowski, Paweł, i Andrzej Włodarek. "Skalbmierz." W Architektura gotycka w Polsce, t. 2, redakcja Teresa Mroczko, Marian Arszyński, 206. Warszawa: Instytut Sztuki PAN, 1995.

Pomfyová, Bibiana. "Ranostredoveké kláštory na Slovensku: torzálna architektúra - torzálne poznatky - torzálne hypotézy.” Archaeologia Historica 40, nr 5 (2015): 733-777. DOI: 10.5817/ AH2015-2-20.

Przybyszewski, Bolesław. Cracovia Artificum: Supplementa. Teksty źródłowe do dziejów kultury i sztuki z archiwaliów kurialnych i kapitulnych w Krakowie 1441-1450. Kraków: Secesja, 1993.

Romanowski, Stanisław. "Dzieje miasta Skalbmierza." Rocznik Muzeum Świętokrzyskiego 3 (1965): 211-304.

"Skalbmierz." W Powiat pińczowski, opracowanie Kazimiera Kutrzebianka, Jerzy Z. Łoziński, Barbara Wolff, 83. Warszawa: Instytut Sztuki PAN, 1961.

Šmied, Miroslav. Praga Sacra. K vizi posvátné Prahy císaře Karla IV. a jejím duchovním kořenům. Praha: Univerzita Karlova v Praze, 2018.

Szymański, Józef. Kanonikat świecki w Małopolsce od końca XI do połowy XIII wieku. Lublin: Agencja Wydawniczo-Handlowa AD, 1995.

Szymborski, Wiktor. Odpusty w Polsce średniowiecznej. Kraków: Historia Iagellonica, 2011.

Szyszko-Bohusz, Adolf. "Beszowa, Skalbmierz i system krakowski." Sprawozdania Komisyi do Badania Historyi Sztuki w Polsce 9, z. 1 (1913): 66-79.

Świechowski, Zygmunt. Katalog architektury romańskiej w Polsce. Warszawa: DiG, 2009.

Tomaszewski, Andrzej. Romańskie kościoły z emporami zachodnimi na obszarze Polski, Czech $i$ Wegier. Wrocław: Ossolineum, 1974. 
Walczak, Marek. "Dlaczego król Kazimierz Wielki zachował od zniszczenia wawelską rotundę Najświętszej Marii Panny.” W Lapides viventes. Zaginiony Kraków wieków średnich. Księga dedykowana profesor Klementynie Żurowskiej, redakcja Jerzy Gadomski, 93-114. Kraków: Wydawnictwo UJ, 2005.

Węcławowicz, Tomasz, i Małgorzata Pietrzykówna. "Maswerki w kościołach Małopolski." Rocznik Krakowski 55 (1989): 45-74.

Węcławowicz, Tomasz. "Małopolska i Ziemie Ruskie Korony." W Architektura gotycka w Polsce, t. 1, redakcja Teresa Mroczko, Marian Arszyński, 61-81. Warszawa: Instytut Sztuki PAN, 1995.

Węcławowicz, Tomasz. Cocto latere nobilitavit. O ceglanych murach kościołów średniowiecznego Krakowa. Kraków: Krakowskie Towarzystwo Edukacyjne-Oficyna Wydawnicza AFM, 2013.

Winterfeld, Dethard von, i Christofer Herrmann. "Kleinpolen." W Mittelalterlische Architektur in Polen: Romanische und Gotische Baukunst zwischen Oder und Weichsel, redakcja Dethard von Winterfeld, Christofer Herrmann, 378-481. Petersberg: Michael Imhof, 2015.

Zoll-Adamikowa, Helena. Wczesnośredniowieczne cmentarzyska szkieletowe Małopolski, cz. 2: Analiza. Wrocław: Ossolineum, 1971. 